Policy Research Working Paper 2052

The Macro Wage Curve and Labor Market Flexibility in Zimbabwe

Dorte Verner
The existence of a macro

wage curve shows that wages in Zimbabwe are flexible. So, the labor market adjusts to both negative and positive economic shocks. The main cause of falling real wages in Zimbabwe is reduced economic activity

The World Bank

Africa Technical Families

Human Development 3

February 1999 
Policy Resharch Working Paper 2052

\section{Summary findings}

There is little available information about what determines money wages in Sub-Saharan Africa - or indeed about whether there is a stable relationship between wages, productivity, GDP, inflation, activity in the informal sector, policy changes, and unemployment.

In studying how wages in Zimbabwe are affected by short- and long-run changes in variables, Verner asks: Are wages affected by prices, unemployment, increased productivity, economic activity, or policy changes? Does a macro wage curve exist? Did structural adjustment cause a structural change in labor markets?
She finds that a macro wage curve does exist, so wages are flexible both generally and in the manufacturing sector. So, the labor market is able to adjust to both positive and negative shocks.

The main cause of falling real wages in Zimbabwe is reduced economic activity.

In the short term, wages are affected by changes in the unemployment rate. They are also affected positively by increases in productivity, prices, and economic activity.

The forecasting performance of the wage determination models shows that they are valid after the implementation of structural adjustment in 1991.

This paper - a product of Human Development 3, Africa Technical Families - is part of a larger effort in the region to understand how labor markets work in Africa. Copies of the paper are available free from the World Bank, $1818 \mathrm{H}$ Street NW, Washington, DC 20433. Please contact Hazel Vargas, room I8-138, telephone 202-473-7871, fax 202-522-2119, Interner address hvargas@worldbank.org. The author may be contacted at dverner@worldbank.org. February 1999. (37 pages)

The Policy Research Working Paper Series disseminates the findings of work in progress to encourage the exchange of ideas about development issues. An objective of the series is to get the findings out quickly, even if the presentations are less than fully polished. The papers carry the names of the authors and should be cited accordingly. The findings, interpretations, and conclusions expressed in this paper are entirely those of the authors. They do not necessarily represent the view of the World Bank, its Executive Directors, or the countries they represent. 


\title{
The Macro Wage-Curve and Labor Market Flexibility in Zimbabwe
}

\author{
Dorte Verner* \\ The World Bank \\ 1818 H Street, N.W. \\ Washington, D.C. 20433 \\ e-mail: dverner@worldbank.org
}

* I am grateful to Helena Ribe for invaluable support, to Niels-Hugo Blunch for excellent research assistance, and to John McIntire for comments. 


\section{Introduction}

There is little available knowledge on what determines money wages in sub-Saharan Africa, or indeed on whether there exists a stable relationship among wages, productivity, GDP, inflation, policy changes and unemployment or informal sector activity. In this paper, we study how wages are affected by short- and long-run changes in the aforementioned variables in the case of Zimbabwe. The importance of knowing the answer to this question may be illustrated by considering economic reforms. Structural adjustment programs may cause reductions in aggregate demand due to decreased government spending and increased real interest rates. If wages are downwards-rigid, and, therefore, unable to adjust to changes in aggregate demand then the unemployment rate or informal sector activity increase. On the other hand, if wages are flexible, then the decrease in aggregate demand may be mitigated by falling wages and, therefore, causing a more limited increase in unemployment or informal sector activity. In the latter case the labor market is characterized by a macro-wage curve.

The main questions addressed are the following: (1) are wages affected by increased productivity, economic activity, prices, policy changes and unemployment; (2) does there exist a macro wage-curve; and, (3) did the economic structural adjustment program (ESAP) cause a structural change in the labor markets. The main findings are that wages are flexible--both upwards and downwards. Hence, the labor market is able to adjust to economic shocks. The main cause of falling real wages in Zimbabwe is reduced economic activity.

This paper is the first in a series of papers studying Zimbabwean labor markets. Another paper analyzes wage and productivity determination in Zimbabwe but in contrast to this paper, the study is based on findings from micro level data (see Verner, 1998). The findings, using data on employees matched with data on firms, can be summarized as: (1) female employees are paid less than males and the negative wage premium do not match a corresponding negative productivity premium; (2) experience is reflected equally in wages and productivity differentials over the life-cycle; (3) the wage premium increases 
with level of education and with occupation title; (4) formal in-house training is found to be associated with higher wages, while there does not seem to be any instant effect on productivity; (5) an additional wage and productivity premium exists if enterprises are engaged in exporting activities; (6) ethnic origin of an employee is not important in the determination of wages. However, Europeans are more productive than other ethnic groups; (7) union members earn less than non-union members despite being found to be more productive; (8) larger firms are more productive and pay higher wages than smaller firms; (9) employees employed in the metal or textile sectors are paid higher wages than colleagues in the food sector.

This paper gives a broad picture of developments in the labor market and it is organized as follows. Section two provides a brief presentation and discussion of economic developments in Zimbabwe. This is followed by a presentation of wage theories and empirical results. Sections three and four contain the estimated wage model and give empirical evidence of whether the labor market in Zimbabwe is characterized by a macrowage curve. The final section provides conclusions.

\section{Trends}

This section contains a brief overview of Zimbabwean labor markets over the past three decades. We apply time series data from 1964 to 1994 to show trends in output, wages, productivity, and employment.

After the declaration of Independence by Rhodesia in 1965 most nations imposed trade sanctions against the regime. This caused a reduced flow of capital goods and industrial inputs from abroad. In 1980 a new government led by Robert Mugabe introduced import quotas and continued controlling prices introduced by the former regime. In the first years after physical capital investment boomed but without investment in long-term commitments to employees, meaning that the production was more capital intensive than labor intensive (Fallon and Lucas; 1993). 
The average annual gross domestic product (GDP) growth rate was 7.5 percent in the period from the declaration of Independence in 1965 until the first oil price increase in 1974. In the same period manufacturing employment increased at an annual rate close to the GDP growth rate (7.2 percent) but the national employment level only grew around 3.7 percent per year. The main explanations of the low employment growth rate are the composition of employment and the relatively low cost of capital as compared to labor costs.

Until 1980, workers of African and European origin had very different opportunities, given the political regime of the time. The latter group obtained the best education and apprenticeships; and most white-collar jobs. African workers were excluded from skilled occupation groups and had no access to training programs or labor unions. Furthermore, wage grids and a minimum wage law did not exist until the 1980s. Fallon and Lucas (1991) report that in 1978 earnings of Europeans were 10.4 times higher than those of Africans. In manufacturing, workers of European origin earned 7.4 times more than Africans. The transition to majority rule in 1980 and the war of Independence in the 1970s made numerous Europeans leave Zimbabwe. In 1992, Europeans represented only one percent of the Zimbabwean population.

\subsection{Output}

Figure 1 shows real output in four sectors together with that of aggregate output in Zimbabwe since 1964. The chart shows that the economic climate improved until the first oil price increase. Afterwards, a recession set in and employment and output declined. The causes of the recession were civil war, emigration, droughts, oil price increases, and trade sanctions.

Whereas real output increased for most sectors over the 1964-94 period, the service and agriculture sectors experienced major drops in output from 1991 onwards. The value of output in the manufacturing sector lies substantially above that of agriculture-for the last 
3 years it is around four times that of agriculture. ${ }^{1}$ The composition of GDP by industrial origin has changed very little over the past 15 years. In 1994, the distribution among agriculture, industry, and services was 15 percent, 36 percent, and 48 percent, respectively (WDR; 1996).

\section{Figure 1}

\section{Sectoral Composition of Output in millions of ZIM\$ (1987 prices)}

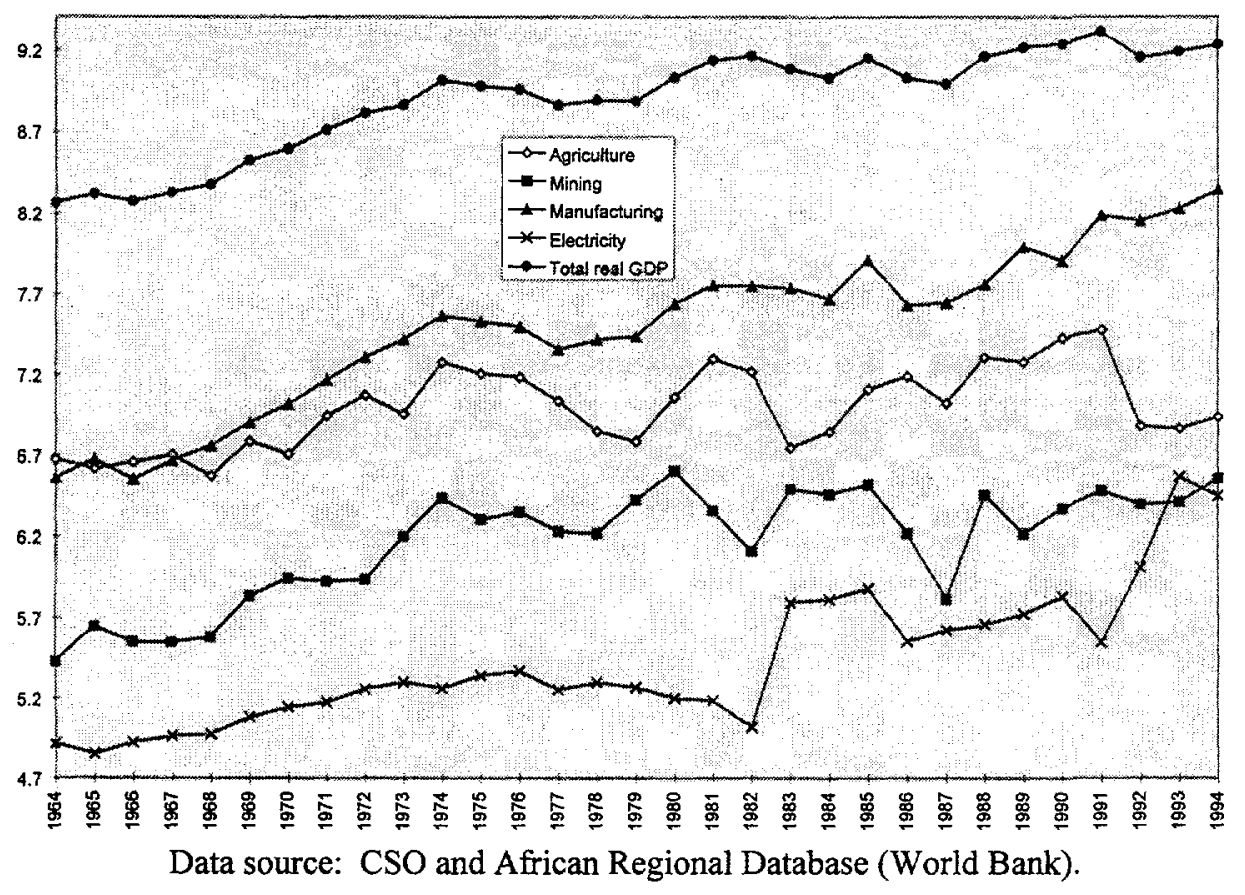

\subsection{Employment}

The active population has increased nearly threefold in the period from 1964 to 1994 . Total wage employment increased by only 72 percent (see Figure 2), and, thus, not been able to absorb the growing labor force. The result is extended informal sector activities and unemployment.

\footnotetext{
${ }^{1}$ See Blunch and Verner (1998) for an analysis of long run sub-Saharan sectoral growth, including the case of Zimbabwe.
} 
Figure 2

Employment and the labor force (1964-94)

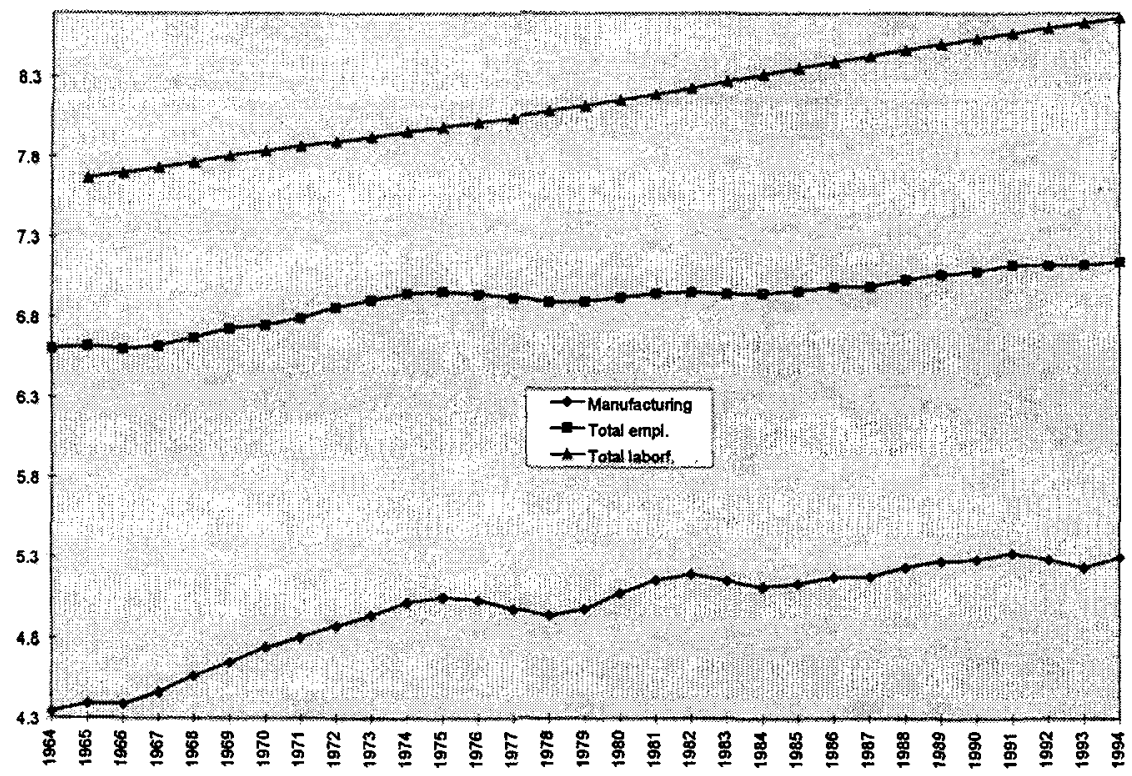

Source: CSO and African Regional Database (World Bank). Note: The series are log.

After a period of civil war Zimbabwe achieved majority rule in 1980 and a new labor legislation was launched. The Riddell Commission that framed the early 1980s legislation argued that the industrial labor market was asymmetric in the bargaining position of managers (of European origin) and workers (of African origin). The new legislation was justified to redress a basically non-competitive (monopsonistic) bargaining structure in the labor market. After 1980, trade unions experienced an increase in memberships and grew in coverage and total employment and output increased. Furthermore, minimum and maximum wages were introduced in recognition of workers needs. However, they were abolished again in 1990 except for agricultural and domestic workers.

In 1990 the government started to deregulate labor markets as part of the general reforms causing a change in the structure of employment. The aims were to reduce the size of the public sector and to reduce public intervention in labor markets. Now, the labor codes are more flexible than in the 1980s as employers can set wages and contracts, retrench, and dismiss employees without consulting the Ministry of Labor (Knight; 1996). 
Figure 3 shows the development in employment by industrial sector in the period from 1964 to $1994{ }^{2}$ The total number of formal employees in Zimbabwe reached 1.263 .700 in 1994, starting at 736.600 in 1964.

The service sector is the largest employer followed by the agricultural and manufacturing sectors. ${ }^{3}$ Employment increased for all three major sectors over the thirty year period. There is no clear trend in agriculture, leading to only a minor increase (10 percent) as compared to 160 percent and 125 percent increase in the manufacturing and service sectors, respectively.

Figure 3

Employment by sector in thousands (1964-94)

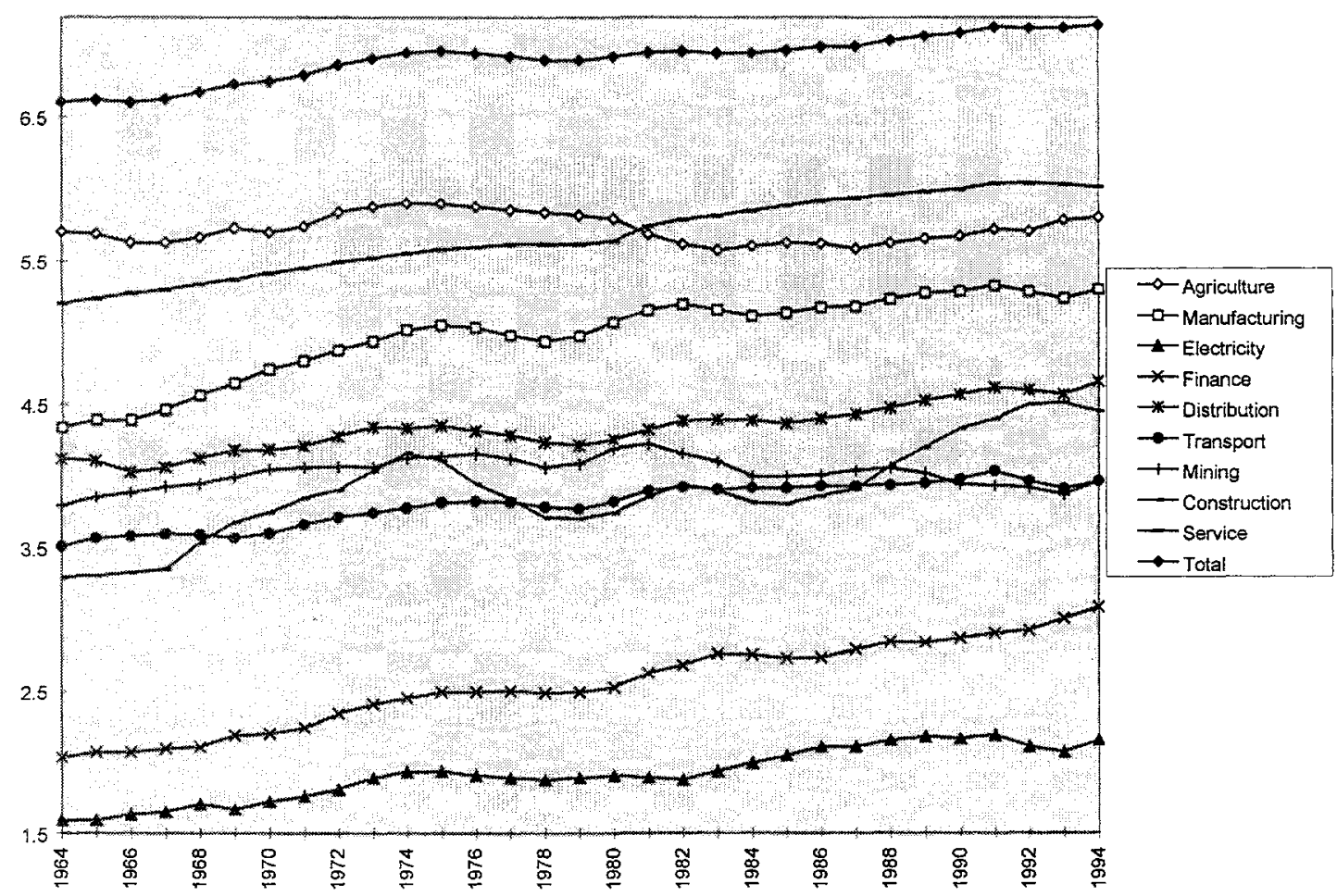

Data source: CSO. Note: Series are log (employees in thousands).

\footnotetext{
${ }^{2}$ The service sector includes public administration, education, health, private domestic, and other.

3 Industry is an aggregation of the following seven sectors: mining and quarrying; manufacturing; electricity and water; construction; distribution, restaurants and hotels; finance; insurance and real estate; and, transport and communications.
} 
Table 1

Annual growth rates of employment in 3 major sectors (percentage)

\begin{tabular}{lccc}
\hline & $1987-90$ & $1991-94$ & $1987-94$ \\
\hline Agriculture & 2.9 & 2.1 & 2.8 \\
Industry & 4.1 & 0.3 & 2.5 \\
Services & 2.2 & -0.3 & 1.4 \\
\hline
\end{tabular}

Data source: own calculations based on CSO statistics.

After the economic structural adjustment program was introduced and droughts took place, the rate of increase in employment slowed significantly in industry, as seen from Table 1. It barely increased in the 1991-94 period. In the same period employment in the service sector decreased yearly by 0.3 percent whereas in agriculture it increased 2.1 percent yearly. The employment loss has been concentrated in sectors vulnerable to competition from trade liberalization and rise in interest rates, such as, for example, textiles. The share of total employment in each sector in the 1987-94 period is pictured in Figure 4.

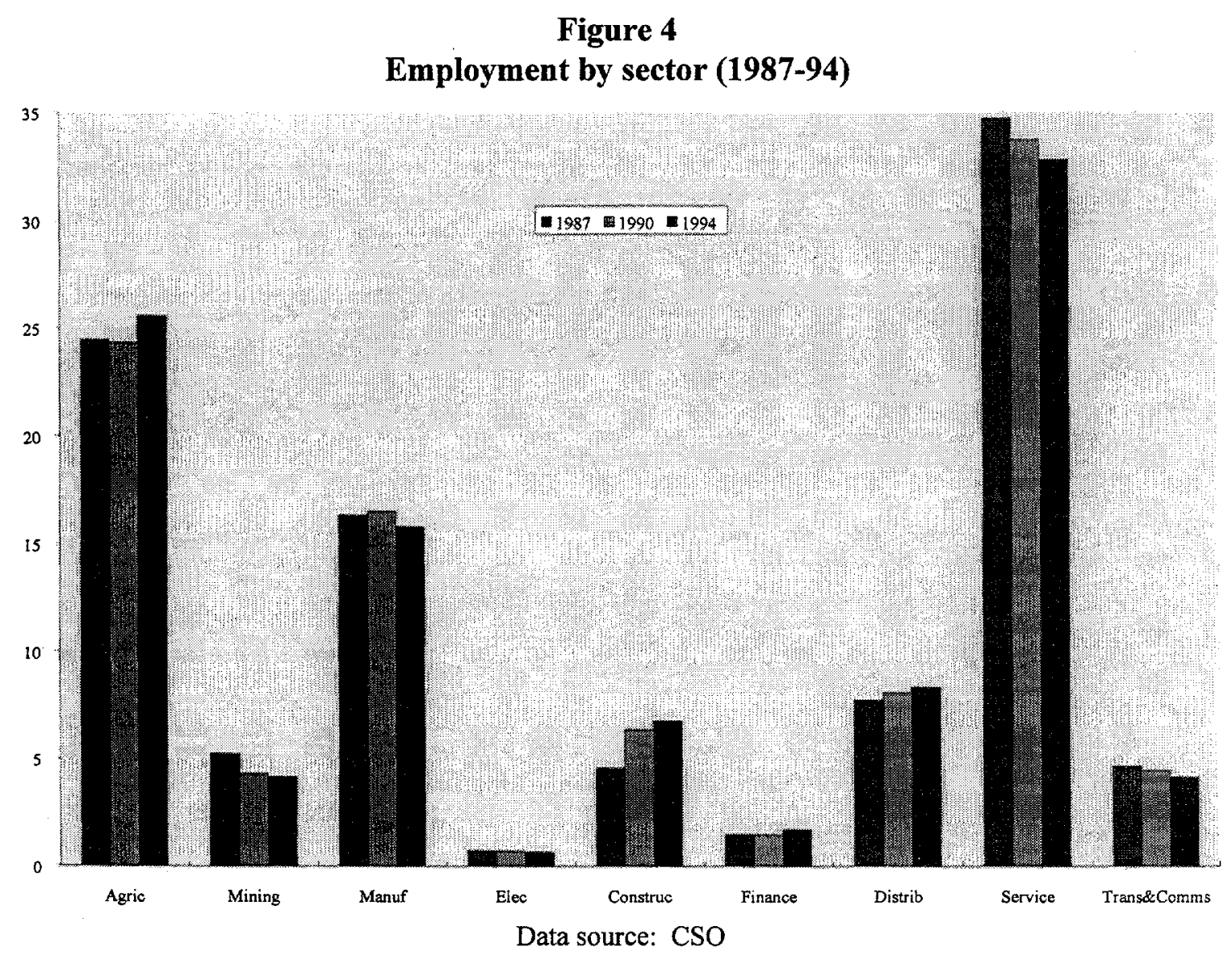


The share of total employment in agriculture, construction, finance, and distribution increased in the 1987-94 period while it decreased in manufacturing, mining, transport/communication, and services; and slightly more in the latter than in the three former sectors.

\subsection{Earnings}

Until 1982 real average wages across sectors as well as real wages in manufacturing were characterized by a positive trend, which was reversed to a negative trend in 1982, see Figure 5. The highest level of average real earnings was in 1982, being 39 percent above the 1979 level (see Figure 6). This was mainly due to the launch of minimum wages (see below).

Figure 5

Total and manufacturing real wages (Zim \$ per year)

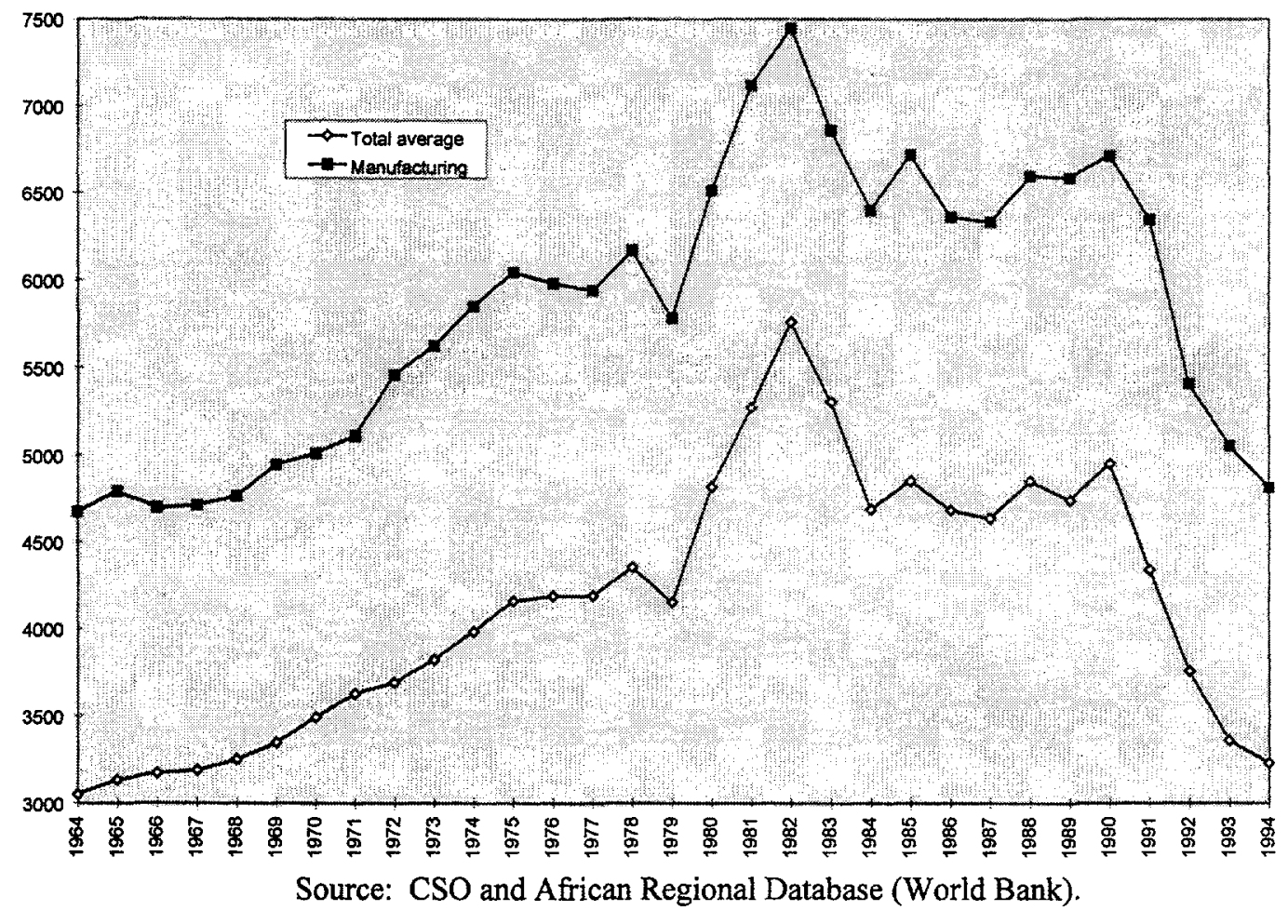


Figure 6

Productivity (Real Output Per Employee ZIM\$)

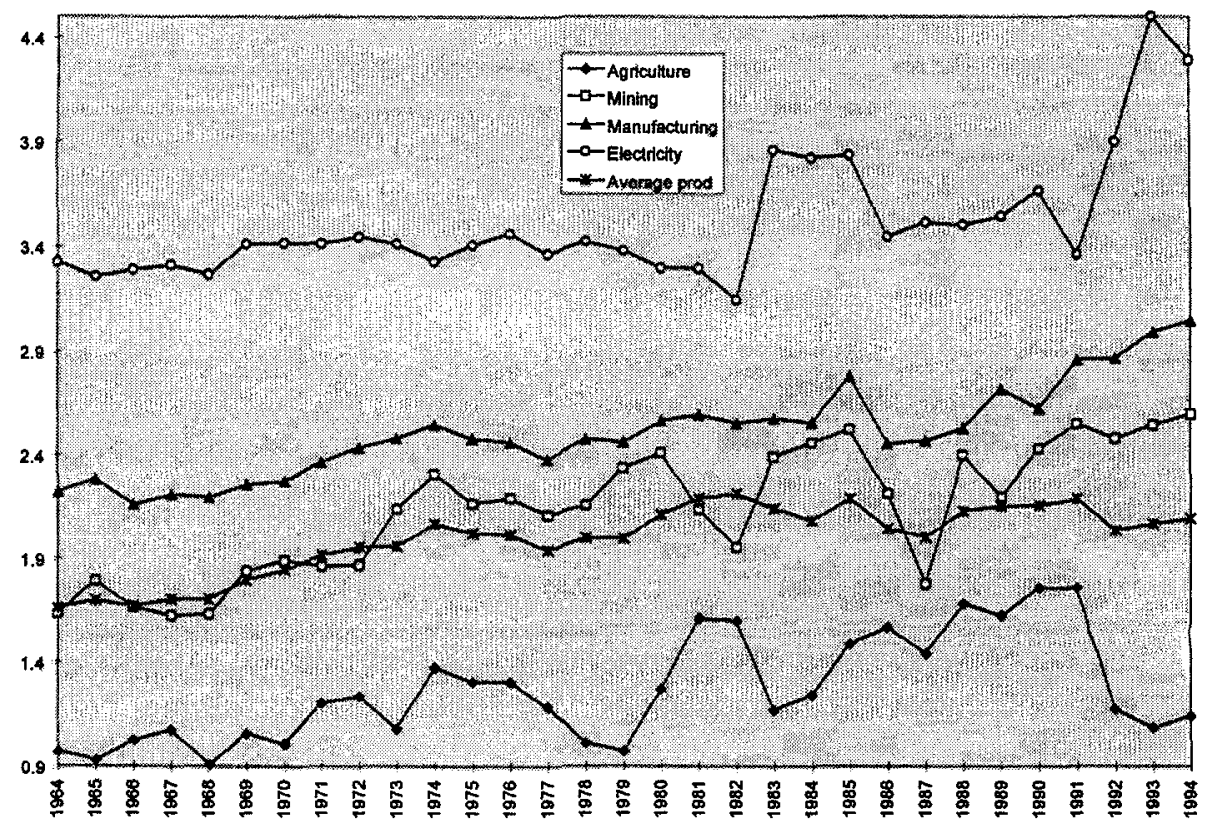

Data source: CSO and African Regional Database (World Bank). Note: All series are log

Figure 6, continued

Productivity (Real Output Per Employee ZIMS)

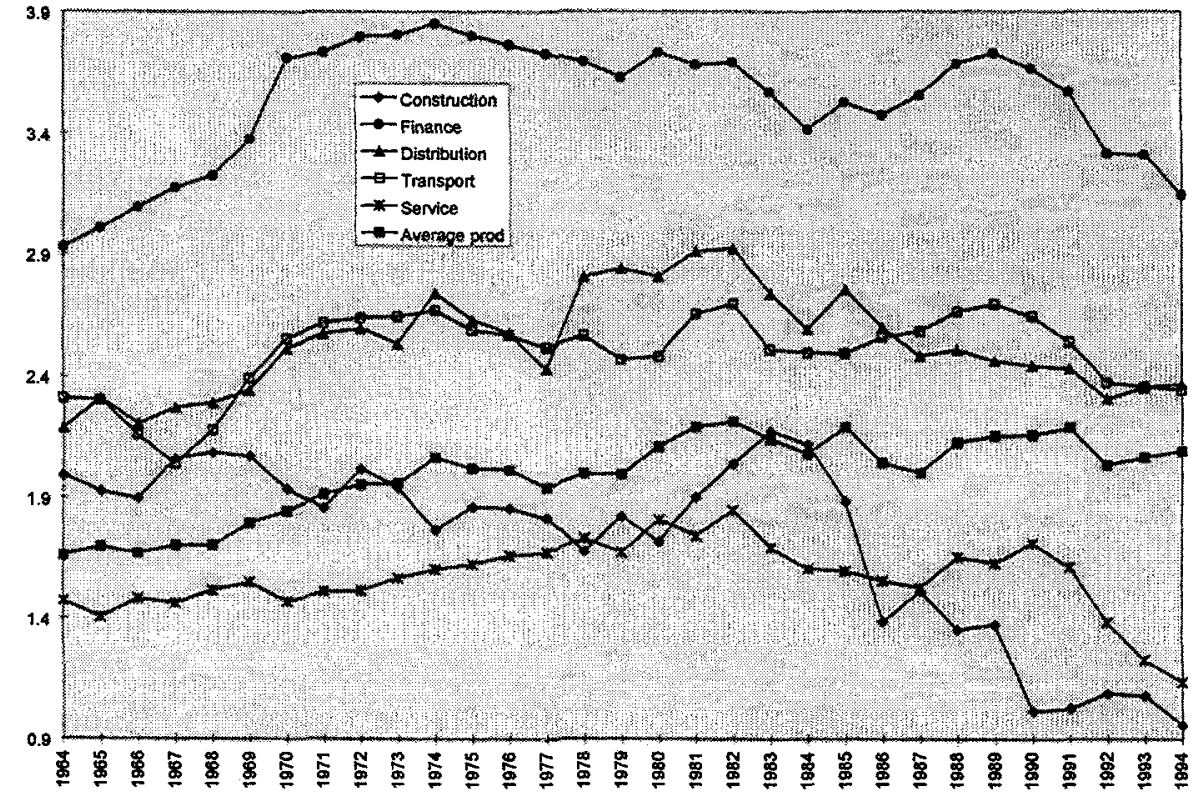

Data source: CSO and African Regional Database (World Bank). Note: All series are log 
In the first three years of the 1990s earnings were reduced 36 percent. Eurthermore, benefits such as, for example, housing and schooling allowances enjoyed by manufacturing sector workers were cut. Earnings in the manufacturing sector were eroded, being 68 percent above average real earnings in 1979 and only 36 percent above in 1990 (Knight; 1996). A decline in real earnings of this magnitude may indicate that the Zimbabwean labor market is rather flexible.

The first government after Independence launched income policies in an attempt to obtain a more equal wage distribution. It actively intervened in the wage determination and launched a minimum wage law. The minimum wage increased rapidly in real terms in the following two years. One consequence of the minimum wage law and the requirement for permission to lay-off and dismiss workers is that employers are unable to offer lower wages, despite being obliged to give greater job security. ${ }^{4}$ In recent years collective bargaining plays a more important role in setting wages in Zimbabwe. The combination of income policies and a rise in the minimum wage following Independence placed a legal boundary on potential, downward real wage adjustments (see Fallon and Lucas; 1993).

Table 2

Average real earnings by sector $(1979=100)$

\begin{tabular}{cccccc}
\hline Year & All sectors & Agriculture & Domestic Service & Mining & Manufacturing \\
\hline & & & & & \\
1989 & 114.7 & 133.3 & 101.8 & 130 & 93.6 \\
1993 & 85 & 86.3 & 47 & 113.1 & 71.1 \\
\hline
\end{tabular}

Source: CSO quarterly.

Also real manufacturing wages fell in the 1980s and 1990s. As earlier mentioned, the number of employees in manufacturing rose during the $1980 \mathrm{~s}$, whereas it was roughly

\footnotetext{
${ }^{4}$ The 1980 Employment Act requires explicit permission from the Ministry of Labor's Retrenchment Committee before any wage or salary employee can be laid-off. Furthermore, contract workers are protected during the contract period. However, employees employed up to six weeks, the so-called casual workers, are totally excluded from the permission clause.
} 
unchanged in the 1990s. In all sectors, real wages fell in the 1990s, whereas in the 1980s real output increased in agriculture and mining, with a falling number of employees, and, therefore, increasing productivity (see Figure 4 and Table 3 ).

Fallon and Lucas (1993) analyze job security, regulation and demand for industrial labor in Zimbabwe. They find a reduction in demand for workers but no slowing in the adjustment of the number of employees following enactment of the labor laws. Furthermore, the drop in employment at the time of the new Employment Act is found not to be associated with mounting European migration or with the structural change in labor demand upon achieving Independence.

\subsection{Productivity}

Economy-wide economic progress requires increased output per worker and it is expected to expand employment opportunities and rise wages. Labor productivity for the 1964-94 period is presented in Figure 6. The charts show that the development in productivity is sector specific. The highest level of productivity is found in electronics and finance. In the mining sector, productivity increased around 162 percent over the period, whereas it was reduced in construction by around 64 percent.

The manufacturing and agricultural sectors productivity show a steady positive trend, having increased by 128 percent and 18 percent, respectively. The service sector, experienced (as the only sector) a decrease in productivity-28 percent--indicating that services may have absorbed the retrenched or less productive labor.

\section{Wage curves}

This subsection briefly describes theories concerned with wages and unemployment that is used in the process of describing wage determination in Zimbabwe. The main economic theories are the so-called Phillips curve (Phillips; 1958) and wage curve (Blanchflower and Oswald; 1995). 
The wage curve can be written as $_{t} w w(u)$, where $w$ is the wage level and $u$ is the unemployment rate. This curve replaces the conventional labor supply function and slopes downwards in the wage-unemployment space. It is often estimated by the following equation:

$$
\ln W=\vartheta \ln U+\text { other terms }
$$

where $\ln W$ is the $\log$ of wages, $\ln U$ is the $\log$ of the unemployment rate, and the other terms are control variables. The $\vartheta$ coefficient denotes elasticity of pay with respect to unemployment. The equation reads that workers earn less in periods of high unemployment or underemployment than in periods with low joblessness. The wage curve, that links the level of pay to the unemployment rate, is concerned with equilibria and not a description of temporary phenomena or transitory dynamics. The Phillips curve, on the other hand, which links the rate of changes of wages to the unemployment rate, can be seen as such a disequilibrium adjustment mechanism. Hence, both models are contained in a single wage determination model when modeling wages in errorcorrection form (see below).

The unemployment elasticity of pay, $\vartheta$, has been estimated using microeconomic data to take the value of -0.1 in many developed countries, for example, in the US, the UK, and Norway (Blanchflower and Oswald; 1995). This implies that a hypothetical doubling of unemployment is associated with a drop in pay of 10 percent. Hence, the unemployment elasticity of pay appears to be of similar magnitude across developed economies, despite sometimes dramatic institutional differences, implying that countries exhibit more uniformity in wage flexibility than a priori expected.

Studies analyzing wage curves in developing countries are scarce. One study by Hoddinott (1996) addresses the question of whether the rate of unemployment affects the wage level in Côte d'Ivoire. The estimated wage-unemployment elasticity is -0.12 . The 
author also estimates the elasticity for the private and public sectors to be -0.18 and -0.11 , respectively.

In the following we apply a linear wage equation building on the above mentioned theories to analyze questions related to the macro-wage curve in Zimbabwe. The model is written:

$$
w_{t}=a+b u_{t}+c p_{t}+d y_{t}+f t
$$

where lower case letters denote the natural logarithms of variables written in upper case letters; $w$ is wages, $u$ is unemployment/informal sector activity and $y$ is GDP (proxies for pressure of demand), $\mathrm{p}$ is prices (proxy for macro economic stability and influence of expectations), and $t$ is a deterministic function of time, capturing productivity increases. We predict that increased productivity impacts wages positively. The same holds for enhanced economic activity and rising prices.

\section{Wage curve estimation}

The determination of Zimbabwean wages is estimated using an error-correction model (ECM). This model allows for analyzing the impact of demand pressure, etc. on wages both in the short and long run. The procedure we apply in estimating the ECM is the Wicken and Breusch (1988) approach. ${ }^{5}$ Hence, this gives an eclectic macro wage model, where we can simultaneously analyze the macro wage curve, the Phillips curve or other economic models of wage determination. The linear wage equation (1) can be formulated as an error correction regression model:

$$
\Delta \mathrm{w}_{\mathrm{t}}=\alpha+\beta \Delta \mathrm{u}_{\mathrm{t}}+\rho \Delta \mathrm{p}_{\mathrm{t}}+\gamma \mathrm{w}_{\mathrm{t}-1}+\lambda \mathrm{u}_{\mathrm{t}-1}+\delta \mathrm{p}_{\mathrm{t}-1}+\varphi \mathrm{t}+\varepsilon_{\mathrm{t}}
$$

\footnotetext{
${ }^{5}$ The reason for this choice is that there is some evidence that the small sample bias is smaller for the longrun estimators than, for example, in the Engle and Granger (1987) two-step procedure [see Kremers, Dolado, and Ericsson (1992)].
} 
where $\Delta$ denotes first differences of the variable. The random disturbance $\varepsilon$ reflects all other factors. The disturbance term may also reflect the fact that we cannot expect data to have been measured with perfect accuracy. The possibility of errors in the measurement of $\mathrm{U}, \mathrm{P}$ and $\mathrm{W}$ is thus another reason for adding a random disturbance term.

The estimate of the long-run parameter, that measures the strength of demand in the labor market on wages, can be obtained from the ratio of the estimated coefficients of $\mathrm{w}_{\mathrm{t}-1}$ and $u_{t-1}$. With the error correction interpretation of equation (1), $\lambda=0$ indicates that there is no effect on wages from increased unemployment. This hypothesis does not preclude labor market effects on wages altogether since changes in the unemployment rate, $\Delta \mathrm{u}$, influence wages provided that $\beta \neq 0$.

The real wage hypothesis, that is, real wages respond to the strength of demand in the labor market, holds if there exists a co-integrating vector involving all long run variables and the sum of the coefficients of $w$ and $p$ equal zero.

Equation (1) has other models of wage determination nested within, for example: (1) a first order error correction model with wages adjusting towards a static equilibrium that depends on prices only $(\beta=\lambda=\varphi=0)$; (2) a first order partial adjustment model with a target value of wages depending on unemployment only $(\beta=\delta=\varphi=0)$; (3) a trend stationary real wage model $(\rho=\delta=1$ and $\beta=\lambda=0$ ); and, (4) a random walk with drift model $(\beta=\rho=\gamma=\varphi=0)$.

We model the economic time series using so-called general-to-specific modeling. This approach has the twin advantages of avoiding unnecessary generality that may result in loss of efficiency and can result in models being too finely tuned to the data. Furthermore, it guarantees the coherence of the model with economic theory, i.e., ensures that the model has an economic interpretation and is related to the phenomena being analyzed. 


\section{Empirical Evidence}

In the following subsection we analyze whether a macro wage curve exists in Zimbabwe using aggregate data from 1964 to 1994 . The statistical model in use is an autoregressive distributed lag model for wages consisting of: (1) pressure of demand that we proxy by the unemployment rate/informal sector and GDP; (2) expectational influences that we proxy by prices; (3) productivity, captured by a deterministic, linear trend; and, (4) important policy changes captured by including dummy variables.

The following three subsections present findings. Subsection 5.1 gives statistical information and subsections 5.2 and 5.3 analyze wage determination in the total economy and the manufacturing sector.

\subsection{Statistical information}

Visual inspections indicate that wages and unemployment have strong positive trends of a similar magnitude, so that they may be modeled as stationary deviations from a linear trend or alternatively as variables with stochastic trends within a co-integrated system (see details in Banerjee, et al. (1993)). The unemployment or informal sector series also exhibits deviations from the trend in form of cyclical movements that will be important to capture in the modeling of wages. These properties, possibly resulting from changes in economic policies and "autonomous" events such as droughts and changes in commodity prices, e.g., crude oil, may be important to take into account when modeling wages.

The inspection of correlograms for the variables $w, p, w-p$, and $u$ reveals high first order serial correlation coefficients (around 0.9) with the higher order coefficients declining extremely slowly, and correspondingly the spectra have peaks at the zero frequency. This information is consistent with each of the series having a stochastic trend and, therefore, being non-stationary and presumably integrated of order one, I(1). The result of the Augmented Dickey-Fuller test supports these hypotheses (see Appendix A). Hence, in modeling wages it will be important to choose models that can represent the 
nonstationarities of the series with the possibility that they form a co-integration relationship. That is, there is some linear combination of the series that is stationary, $I(0)$.

\subsection{Wage determination for the total economy}

This section presents results on wage determination and it should be noted that we have problems with regard to the number of data points when we want to introduce both pressure-of-demand variables - the unemployment rate/informal sector and GDP. The series are very highly correlated and, therefore, the high simple correlation may indicate multicollinearity problems. One way to solve this problem is to include all demand pressure variables and the cross-products of these in the error correction specification of the wage model. This is clearly the ideal scenario but data are only available for three decades, therefore, it is not statistically feasible. Another way to model wages is by including one demand pressure variable at a time, in both levels and changes, in the model and subsequently perform encompassing tests to uncover which demand pressure variable best explains wages.

\subsubsection{The aggregate wage model with the unemployment rate}

In this subsection, we explain wages by prices, the unemployment rate/informal sector activity, productivity (trend), and policy dummy variables. Recursive estimation shows that the pattern of wages in the period from 1980 to 1984 is out of line with the estimated pattern of the wage model-they are too high. ${ }^{6}$ A congruent model is produced, by taking into account that in this period, wages were set higher than could be sustained by economic activity and productivity. There are no obvious signs of misspecifications for the full data sample when including policy dummy variables: i1984 (an impulse dummy, which takes the value one in 1984 and zero elsewhere) and i80-84 (step dummy, which takes the value of one in each year in the 1980-84 period and zero else where). Policies introduced after the Independence War (1980) appear to have led to a large acceleration in wage inflation revealed by the positive parameter estimate (see Table 3).

\footnotetext{
${ }^{6}$ This is revealed by recursive estimation followed by tests statistics for structural break points. One-stepahead Chow tests informed that changes took place in the labor market in the period from 1980 to 1984.
} 
Table 3

ECM for total wages

\begin{tabular}{|c|c|c|c|c|c|c|}
\hline Variable & Coefficient & Std. Error & $t$-value & $t$-prob & Part $R^{2}$ & Instab \\
\hline$-U$ & -1.392 & 0.521 & -2.671 & 0.015 & 0.263 & 0.16 \\
\hline CPI_1 & 0.103 & 0.058 & 1.782 & 0.090 & 0.137 & 0.03 \\
\hline$-\mathrm{CPI}$ & 0.098 & 0.135 & 0.727 & 0.476 & 0.026 & 0.03 \\
\hline Trend & 0.028 & 0.010 & 2.902 & 0.009 & 0.296 & 0.03 \\
\hline Constant & 2.765 & 1.295 & 2.135 & 0.045 & 0.186 & 0.03 \\
\hline W_1 & -0.253 & 0.112 & -2.266 & 0.035 & 0.204 & 0.03 \\
\hline U_1 & -0.383 & 0.269 & -1.423 & 0.170 & 0.092 & 0.04 \\
\hline i80-84 & 0.086 & 0.019 & 4.505 & 0.000 & 0.504 & 0.03 \\
\hline i1984 & -0.118 & 0.034 & -3.492 & 0.002 & 0.379 & 0.07 \\
\hline \multicolumn{7}{|c|}{ Definitions of Variables } \\
\hline \multicolumn{7}{|c|}{$\begin{array}{c}\text { W_1 is log total wages lagged once } \\
U_{-} 1 \text { is log total unemployment rate lagged once } \\
-U \text { is the first order difference of } U \\
\text { CPI_1 is the log of the consumer price index lagged once } \\
-\mathrm{CPI} \text { is the difference of CPI } \\
\text { iXXXX is a dummy variable for the(se) year(s) }\end{array}$} \\
\hline \multicolumn{7}{|c|}{\begin{tabular}{|c|} 
Test Statistics \\
\end{tabular}} \\
\hline \multicolumn{7}{|c|}{$\begin{array}{c}\mathrm{R}^{2}=0.791 \mathrm{~F}(8,20)=9.436[0.000] \sigma=0.029 \mathrm{DW}=2.54 \\
\mathrm{RSS}=0.017 \text { for } 9 \text { variables and } 29 \text { observations } \\
\text { Variance instability test: } 0.385 \text { Joint instability test: } 1.943 \\
\text { Information Criteria: } \mathrm{SC}=-6.393 \mathrm{HQ}=-6.684 \mathrm{FPE}=0.001\end{array}$} \\
\hline
\end{tabular}

Additionally, Table 3 summarizes test statistics and based on these statistics; there is no evidence of misspecification of the wage model. ${ }^{7}$ The charts presented in Figure 7 substantiate these findings showing the actual and the fitted values, the residuals, the

\footnotetext{
${ }^{7}$ The variance instability and the joint instability test statistics; a Lagrange multiplier (LM) test for autocorrelation in the residuals with the null of no serial correlation (AR); an LM statistic for testing the null of no autoregressive conditional heteroscedasticity (ARCH); a statistic for testing the null hypothesis of unconditional homoscedasticity against the alternative that the residuals are correlated with the model's regressors and their squares $\left(\mathrm{Xi}^{2}\right)$; a regression specification test which test the null of correct specification against the alternative that the residuals are correlated with the squared fitted values of the regressand (RESET); and the test statistic for normality, where the null is that the residuals are normally distributed.
} 
residual correlogram, and the residual frequency plot and density. Additionally, the recursive least square estimates of the model reveal no serious indications of parameter non-constancy (see Figure 8 ). ${ }^{8}$

The eclectic macro wage model combines the Phillips curve, the real-wage models and other wage determination models. The estimates reveal no strongly significant effect on nominal wages from increased unemployment in the long term. That is, we cannot reject the null hypothesis that the impact of the unemployment rate or informal sector activity on wages is zero (see Table 4). This indicates that this measure of the strength of demand in the labor market on wages is not very important in the long run in Zimbabwe. The informal sector is a buffer absorbing individuals lacking the skills required for working in the formal sector.

Since wages are not affected significantly by the unemployment rate or informal sector activity there seems not to be any long-run trade-off between the two. However, labor markets do affect wages through the growth rate or changes in the unemployment rate, that is, in the short term. An increase in the volatility or growth rate of unemployment affects nominal wages negatively, everything else equal.

Regression findings indicate that expectations, proxied by prices, marginally affect nominal wages in the long run but not in the short run. The latter coefficient is not statistically significantly different from zero, while the former is statistically significant and positive. This finding is expected as wages have not been indexed to prices in Zimbabwe neither before nor after Independence. Real wages are eroded in the short run

\footnotetext{
${ }^{8}$ See Doornik and Hendry (1995).
} 
Figure 7

Residual plots, ECM for total wages

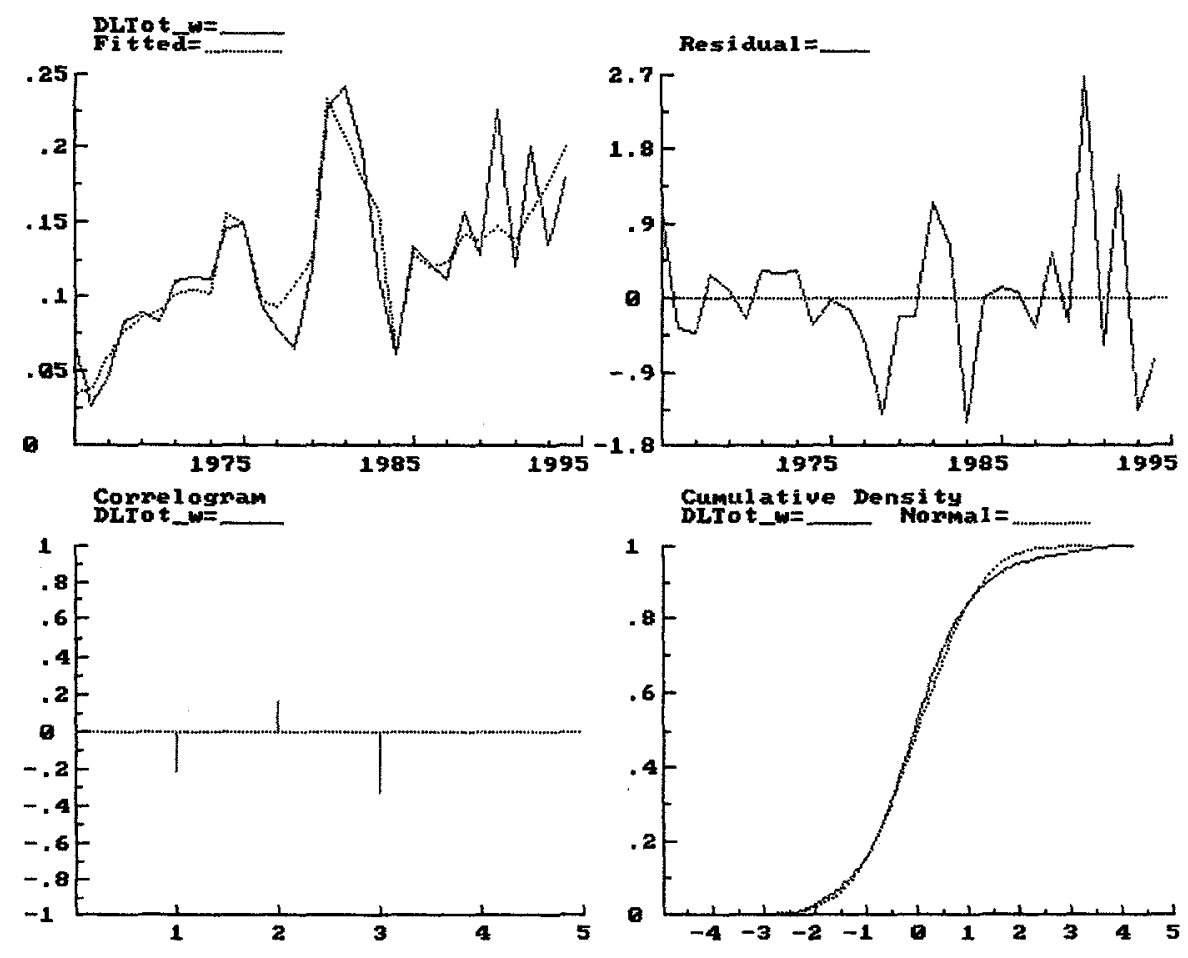

Figure 8

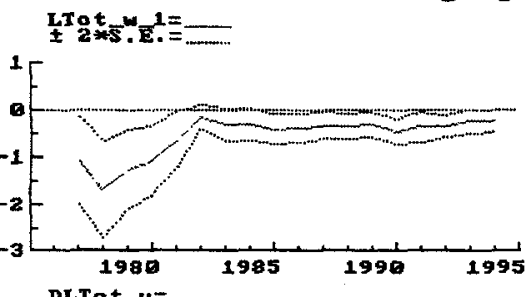

Recursive graphics for total wages
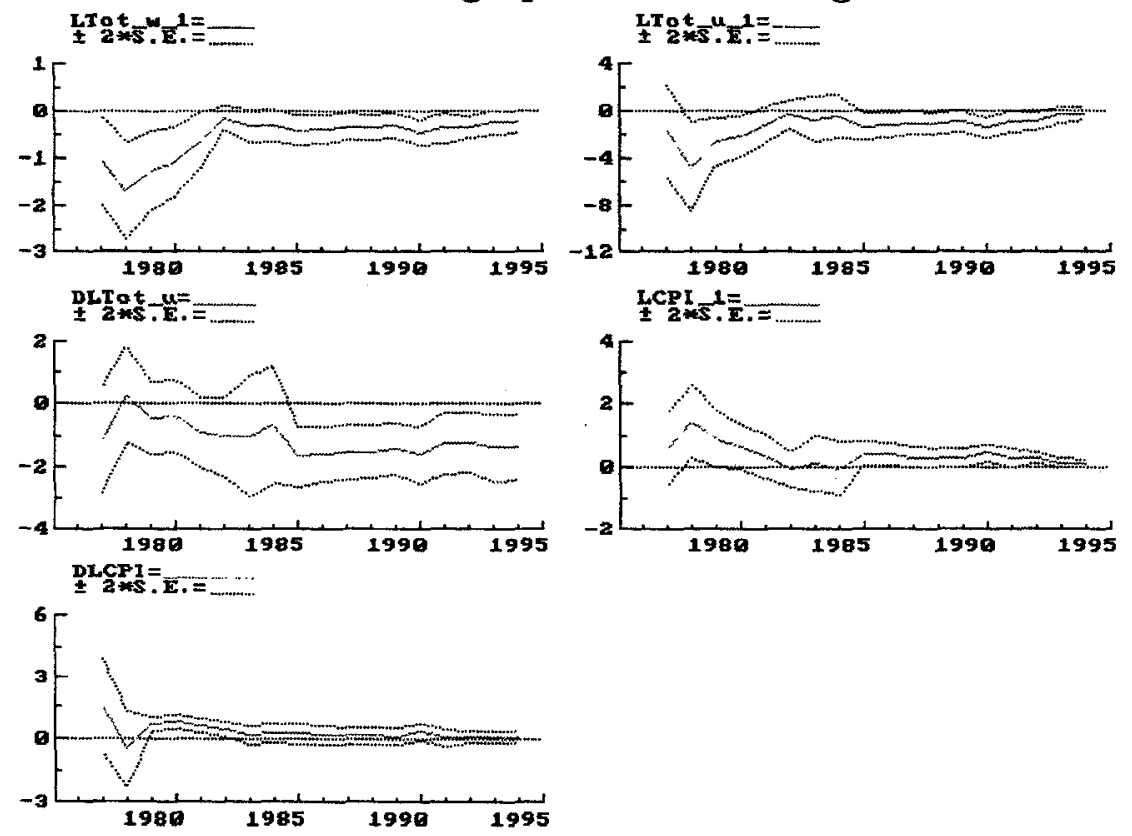
since wages are not instantaneously adjusted to price increases. Meanwhile, in the longer term a price increase impacts nominal wages positively, ceteris paribus. The same is true for productivity; estimated to be statistically significant and different from zero. Hence, an increase in productivity leads to a wage increase.

The estimated coefficient on the level of nominal wages is negative, less than one and is statistically significantly different from zero. The overall implication of a negative coefficient estimate on the wage term (W_1) is that we can use the wage equation to obtain a "long-run equilibrium solution" of the error-correction type. 9 The solved longrun equation with zero autonomous growth $\left(\Delta \mathrm{w}=\Delta \mathrm{u}_{\mathrm{t}}=\Delta \mathrm{p}_{\mathrm{t}}=0\right)$ for the model presented in Table 3 is:

$$
w=10.9-1.5 u+0.4 p+0.11 t
$$

which describes a highly significant error-correction mechanism between wages, employment and prices (Wald test statistics for the hypothesis that all coefficients including those of the 2 dummy variables but excluding the constant term are zero: $F(8,20)=9.44[0.00])$. However, the unemployment rate seems to have no role to play in the error correction mechanism as wages in the long term appear to be unaffected by the level of unemployment in Zimbabwe. The hypothesis that the unemployment rate does not affect wages, $\lambda=0$ in equation (1), is not rejected $(F(1,20)=2.02[0.17])$.

Now we turn to the steady state solution of the wage model presented in Table 3 and rewriting it gives the estimated steady state:

$$
\mathrm{w}_{\mathrm{t}}=10.9+0.4 \mathrm{p}_{\mathrm{t}}+0.1 \mathrm{t}-1.5 \mathrm{u}_{\mathrm{t}}-5.5 \Delta \mathrm{u}^{*}+0.4 \Delta \mathrm{p}^{*}
$$

\footnotetext{
${ }^{9}$ See, e.g., Hendry (1980).
} 
The steady state is consistent with the growth of wages implied by the long-run equation (2). One implication for wages is that the equilibrium value of nominal wages is smaller ceteris paribus the larger the steady state growth rate of the unemployment rate when it is positive. Hence, the equilibrium value of the nominal wage ceteris paribus is associated negatively with increases in the unemployment growth rate. Another implication of the steady state equation is that the equilibrium value of nominal wages is larger ceteris paribus the larger is the steady state inflation rate when the latter is positive. The impact on wages from increased inflation is not one to one. Ten percentage points increase in inflation is associated with 4 percentage points increase in wages. Hence, inflation erodes wages in the long run.

Is there a wage determination model that fits the Zimbabwean data? First, we test whether the Zimbabwean data fit a real wage specification. The results indicate that real wages do not respond to the strength of demand in the labor market. Furthermore, the real wage hypothesis only holds if: (1) the restriction $(w-p)=0$ cannot be rejected; and (2) there exists a co-integrating vector involving all three variables $\mathrm{w}, \mathrm{u}$ and $\mathrm{p}$ which has the sum of the coefficients equal zero. The first restriction cannot be rejected at a 1 percent significance level but is rejected at 5 percent $\left(F(1,20)=4.84[0.04]^{*}\right)$. Moreover, there does not exist a co-integrating vector containing all three variables. Hence, the real wage hypothesis can be rejected.

Second, we test other models of wage determination nested within the one presented in Table 4: (1) a first order error-correction model with wages adjusting towards a static equilibrium that depends on prices only $(\beta=\lambda=\varphi=0)$ and this model cannot be rejected at a 1 percent level of significance but is rejected at a 5 percent level $(F(1,20)=4.85$ $\left.[0.04]^{*}\right)$; (2) a first order partial adjustment model with a target value of wages depending on unemployment only $(\beta=\delta=\varphi=0)$ is highly rejected $(F(3,20)=6.89$ [0.00]); and (3) a trend stationary real wage model $(\rho=\delta=1$ and $\beta=\lambda=0)$, this hypothesis is highly rejected $F(4,20)=75.06[0.00])$; 
Hence, no macro-wage curve can be revealed using unemployment as pressure of demand variable as the level of unemployment plays no significant role in the longer term in explaining nominal wages.

Table 4

ECM for total wages (including GDP)

\begin{tabular}{|c|c|c|c|c|c|c|}
\hline Variable & Coefficient & Std. Error & $\mathrm{t}$-value & t-prob & Part $\mathrm{R}^{2}$ & Instab \\
\hline$W_{-1}$ & -0.317 & 0.105 & -3.008 & 0.007 & 0.301 & 0.05 \\
\hline Constant & 2.471 & 1.183 & 2.09 & 0.049 & 0.172 & 0.05 \\
\hline CPI_1 & 0.089 & 0.053 & 1.664 & 0.111 & 0.117 & 0.05 \\
\hline$-\mathrm{CPI}$ & -0.023 & 0.131 & -0.172 & 0.865 & 0.001 & 0.05 \\
\hline GDP_1 & 0.099 & 0.038 & 2.649 & 0.015 & 0.250 & 0.05 \\
\hline -GDP & 0.083 & 0.036 & 2.312 & 0.031 & 0.203 & 0.04 \\
\hline Trend & 0.022 & 0.009 & 2.534 & 0.019 & 0.234 & 0.05 \\
\hline i1 1984 & -0.114 & 0.034 & -3.364 & 0.003 & 0.350 & 0.05 \\
\hline i80-84 & 0.086 & 0.019 & 4.613 & 0.000 & 0.503 & 0.03 \\
\hline \multicolumn{7}{|c|}{ Definitions of Variables } \\
\hline \multicolumn{7}{|c|}{$\begin{array}{c}\text { W } 1 \text { is log total wages lagged once } \\
U_{-} 1 \text { is } \log \text { total unemployment rate lagged once } \\
-U \text { is the first order difference of } U \\
\text { CPI_1 is the log of the consumer price index lagged once } \\
- \text { CPI is the difference of CPI } \\
\text { GDP } 1 \text { is the log of GDP lagged once } \\
\text {-GDP is the first order difference of GDP } \\
\text { iXXXX is a dummy for the(se) year(s) }\end{array}$} \\
\hline \multicolumn{7}{|c|}{ Test Statistics } \\
\hline & $\begin{array}{r}\mathrm{R}^{2}=0.788 \mathrm{~F}(8 \\
\mathrm{RSS}=0 \\
\text { Variance insta } \\
\text { Information Criteri } \\
\mathrm{A} \\
\mathrm{AF} \\
\mathrm{NC}\end{array}$ & $\begin{array}{l}=9.7442[ \\
\text { for } 9 \text { variab } \\
\text { ty test: } 0.439 \\
\mathrm{SC}=-6.396 \\
-2 \mathrm{~F}(2,19) \\
1 \mathrm{~F}(1,19) \\
\text { ality } \mathrm{Chi}^{2}(2) \\
\mathrm{F}(16,4)= \\
\mathrm{T} F(1,20)\end{array}$ & $\begin{array}{l}D 00] \sigma= \\
s \text { and } 30 \\
\text { Joint insta } \\
Q=-6.68 \\
0.869[0.4 \\
0.035[0 . \\
6.940[0 . \\
16[0.90 \\
0.165[0 .\end{array}$ & $\begin{array}{l}29 \mathrm{DW} \\
\text { ervation } \\
\text { ity test: } \\
\text { FPE =0 } \\
\text { ] } \\
\text { 3] } \\
\text { 1] } \\
\text { 9] }\end{array}$ & $\begin{array}{l}2.33 \\
97 \\
111629\end{array}$ & \\
\hline
\end{tabular}




\subsubsection{Aggregate model with GDP}

In this subsection we introduce GDP as the main pressure-of-demand variable, while in the former sub-section we used the unemployment rate. We present our findings in Table 4. Again, nominal wages are explained by prices, a deterministic time trend, policy dummy variables, and our pressure of demand variable, GDP. As above, the pattern of wages in the beginning of the 1980 s is out of line with the developments of the economy. That is, wages are too high and to capture this, we include dummy variables (D1984 and D80-84). On the basis of the diagnostic test statistics presented in the bottom of Table 4 and charts presented in Figures 9 and 10, we observe no evidence of model misspecification.

The findings reveal that the pressure-of-demand variable affects wages positively both in the short and long term, revealed by the statistically significant impact on wages from both GDP growth and GDP in levels. This indicates that the strength of demand in the labor market is important for Zimbabwean wages.

Figure 9

Residual plots, ECM for total wages (including GDP)

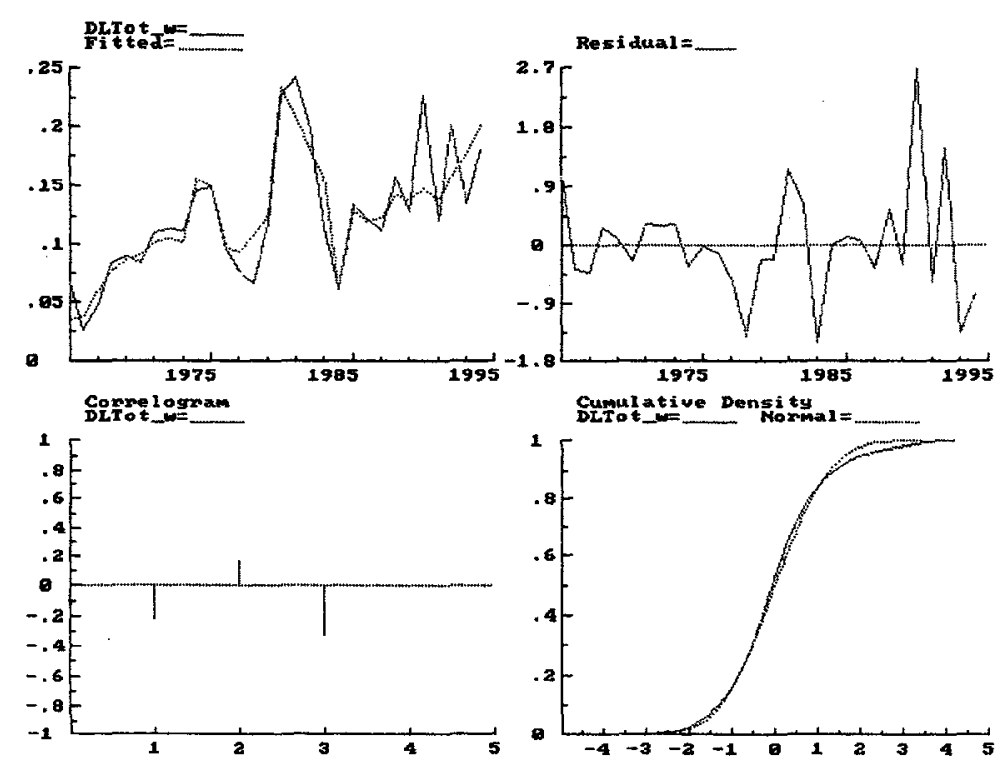




\section{Figure 10}

Recursive plots, ECM for total wages (including GDP)

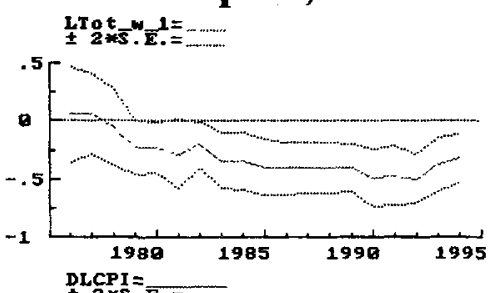

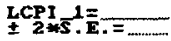
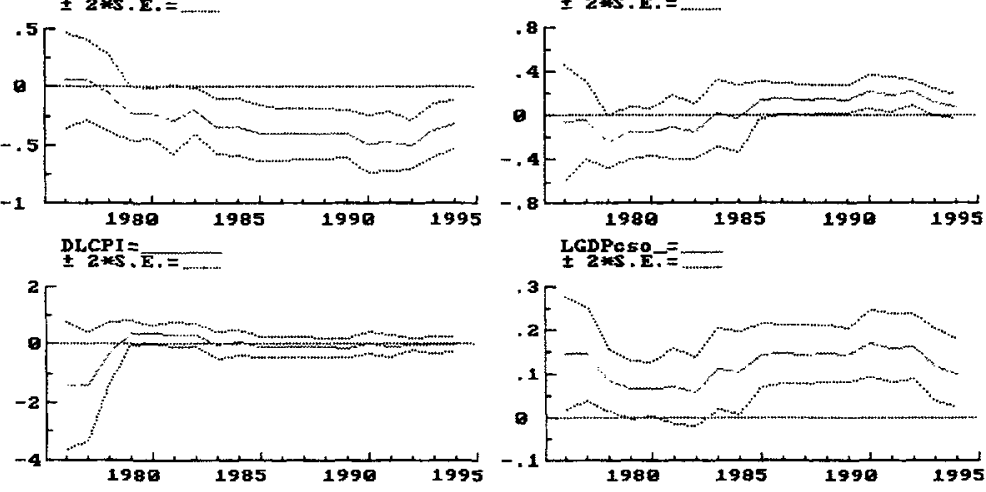

$\underset{ \pm 2}{\operatorname{LGDSO}}=$

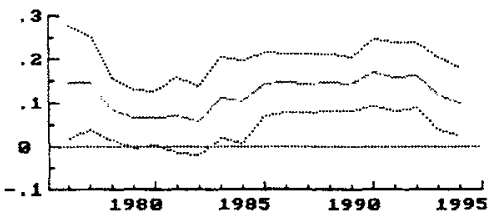
DLGDPCSO=

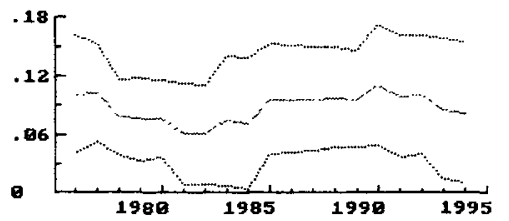

Expectations, measured by prices, marginally affect wages positively in the long run but not in the short run. Furthermore, productivity affects the wage determination process positively. These coefficients are estimated to be statistically significant and different from zero.

We find that the wage term (W_1) is statistically significant and the coefficient is negative, hinting at the existence of a long run relationship between GDP, prices, productivity, and employment. Furthermore, the hypothesis that the sum of the coefficients of $w, u$ and $p$ equals zero cannot be rejected $(F(1,21)=4.27[0.05])$ and all variables are significantly different from zero. Hence, there exists a co-integrating vector involving all variables, and we can use the wage equation to obtain a long-run equilibrium solution. The solved long-run equation with zero autonomous growth, $\Delta \mathrm{w}=$ $\Delta \mathrm{GDP}=\Delta \mathrm{p}=0$, is:

$$
\mathrm{w}=7.8+0.3 \mathrm{GDP}+0.3 \mathrm{p}+0.1 \mathrm{t}
$$


which describes a significant error-correction mechanism between wages, GDP, productivity and prices (the Wald test statistics for the hypothesis that all coefficients including those of the 2 dummy variables but excluding the constant are zero: $F(8,21)=$ $9.74[0.00])$. Hence, in the long term wages are affected positively by increases in economic activity, prices, and productivity. A one percentage point increase in GDP is associated with 0.3 percentage points increase in nominal wages, everything else equal. Ten percentage points increase in prices or productivity impacts wages by 2.8 and 0.7 percentage points, respectively.

Therefore, the steady state for the model has the form:

$$
\mathrm{w}_{\mathrm{t}}=7.8+0.3 G D P_{\mathrm{t}}+0.3 \mathrm{p}_{\mathrm{t}}+0.1 \mathrm{t}+0.3 \Delta \mathrm{GDP}^{*}-0.1 \Delta \mathrm{p}^{*}
$$

implying that the equilibrium value of nominal wages is larger the larger the steady state growth rate of GDP, when it is positive, ceteris paribus. Hence, the equilibrium value of the nominal wage is associated positively with increases in the GDP growth rate, ceteris paribus. The other implication of the steady state equation is that the equilibrium value of nominal wages is smaller the larger is the steady state inflation rate when the latter is positive, ceteris paribus.

Does there exist a wage determination model that fit the Zimbabwean data using this wage specification? We find that the real wage hypothesis cannot be rejected at a 5 percent level of significance $(F(1,21)=6.98[0.015])$. Furthermore, this model explains 79 percent of the variation in wages in the last three decades. We test other models of wage determination nested within the model shown in Table 5; all of these are rejected by data. $^{10}$

\footnotetext{
${ }^{10}$ The hypothesis that wages are determined by a first order error correction model with wages adjusting towards a static equilibrium that depends on prices only can be rejected $(\mathrm{F}(3,21)=6.90[0.00])$. Furthermore, the hypothesis that wages follows a first order partial adjustment model with target values of wages depending on unemployment only can be rejected $F(3,21)=5.27[0.01]$; and so can the hypothesis of a trend stationary real wage model $(F(4,21)=77.78[0.00])$.
} 


\subsubsection{Comparing the aggregate models}

We compare the wage models from the different specifications estimated above (presented in Table 3 and 4). We find that the main difference between the estimated models relates to the demand pressure variables. The impacts on wages from prices are of the same signs and magnitude in both specifications, the same holds for productivity and policy variables. These results highlight the role of expectations and macroeconomic stability in the Zimbabwean wage determination process.

\section{Table 5}

\section{Encompassing test statistics}

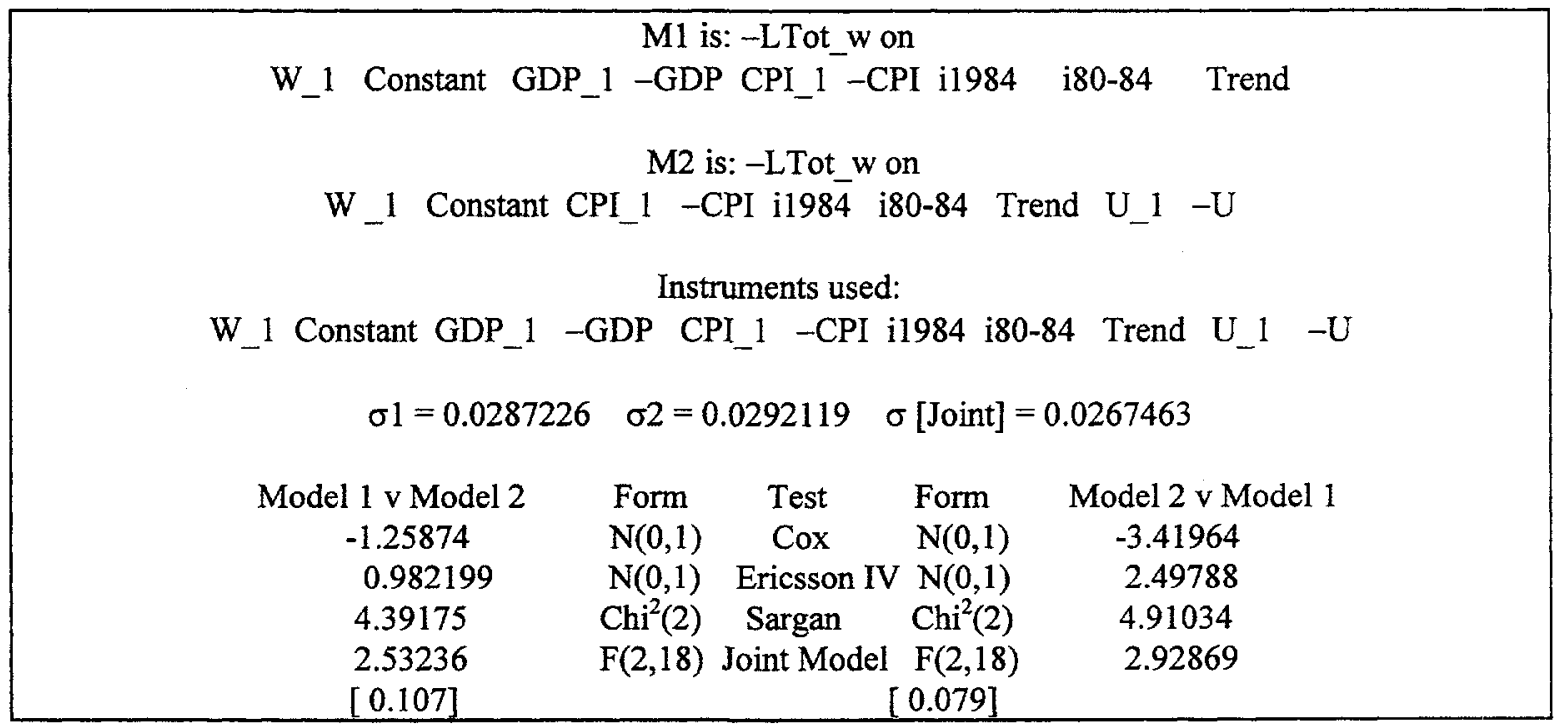

An encompassing test offers one way of comparing the two wage models to reveal whether one contains information not captured in the other. Table 5 reports four test statistics that compare whether model [M1] with GDP encompasses model [M2] with the unemployment rate.

All test results on the left hand side in the table are statistically insignificant; therefore model 1 is not rejected against model 2. The right-hand side reveals that model 2 also encompasses model 1. Hence, neither model contains information not already captured in the other. Both ways of modeling aggregate wages with Zimbabwean data contain the 
same information. Since we in M1 find a long-run relationship between all the variables this is our preferred and also final selected model.

Table 6

ECM for Manufacturing wages

\begin{tabular}{|c|c|c|c|c|c|c|}
\hline Variable & Coefficient & Std. Error & $t$-value & t-prob & PartR $^{2}$ & Instab \\
\hline$\overline{C P I \_1}$ & -0.099 & 0.070 & -1.425 & 0.170 & 0.092 & 0.09 \\
\hline$-\mathrm{CPI}$ & -0.245 & 0.176 & -1.394 & 0.179 & 0.089 & 0.08 \\
\hline U_1 & 0.760 & 0.556 & 1.368 & 0.186 & 0.086 & 0.11 \\
\hline$-U$ & -2.005 & 0.793 & -2.528 & 0.02 & 0.242 & 0.15 \\
\hline Man-W_1 & -0.168 & 0.078 & -2.161 & 0.043 & 0.189 & 0.09 \\
\hline Constant & -0.684 & 0.360 & -1.898 & 0.072 & 0.153 & 0.1 \\
\hline GDP_1 & 0.242 & 0.085 & 2.849 & 0.010 & 0.289 & 0.09 \\
\hline -GDP & 0.165 & 0.061 & 2.735 & 0.013 & 0.272 & 0.1 \\
\hline $\mathrm{i} 80-84$ & 0.067 & 0.025 & 2.672 & 0.015 & 0.263 & 0.08 \\
\hline \multicolumn{7}{|c|}{ Definitions of Variables } \\
\hline i80-84 i & \multicolumn{5}{|c|}{$\begin{array}{c}\text { Man-W_1 is log manufacturing wages lagged once } \\
U_{-} 1 \text { is log total unemployment rate lagged once } \\
-U \text { is the first order difference of } U \\
\text { CPI_1 is the log of the consumer price index lagged once }\end{array}$} & erwise \\
\hline \multicolumn{7}{|c|}{ Test Statistics } \\
\hline \multicolumn{7}{|c|}{$\begin{array}{c}\mathrm{R}^{2}=0.718 \mathrm{~F}(8,20)=6.360[0.000] \sigma=0.040 \mathrm{DW}=1.20 \\
\mathrm{RSS}=0.031 \text { for } 9 \text { variables and } 29 \text { observations }\end{array}$} \\
\hline & & $\begin{array}{l}2 \mathrm{~F}(2,18) \\
1 \mathrm{~F}(1,18 \\
\text { lity } \mathrm{Chi}^{2}(2 \\
\mathrm{F}(16,3)= \\
\mathrm{T} \mathrm{F}(1,19)\end{array}$ & $\begin{array}{l}.700[0 . \\
0.251[0 \\
9.874[0 \\
534[0.8 \\
4.847[0\end{array}$ & & & \\
\hline
\end{tabular}




\subsection{Wage determination in the manufacturing sector}

In this section we focus on the manufacturing sector. We explain manufacturing sector wages by prices, the unemployment rate, GDP and policy. The analysis shows that also the pattern of wages in the manufacturing sector is out of line with the development in the economy in the beginning of the 1980 s-they are too high. By including a policy variable, no obvious misspecification problems remain in the model. The charts presented in Figures 10 and 11 substantiate findings in Table 6 of no misspecification of the model and no indications of parameter non-constancy.

Figure 11

\section{Residual plots, ECM for Manufacturing wages}
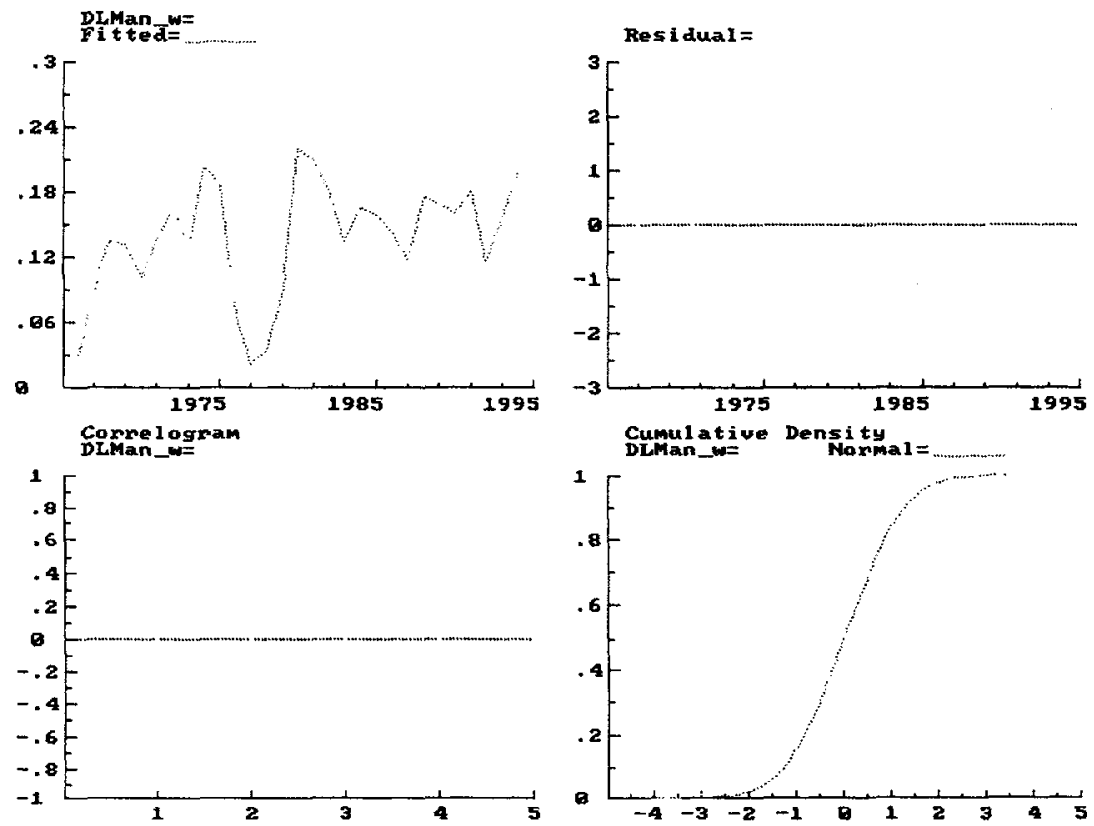


\section{Figure 12}

\section{Recursive plots, ECM for manufacturing wages}
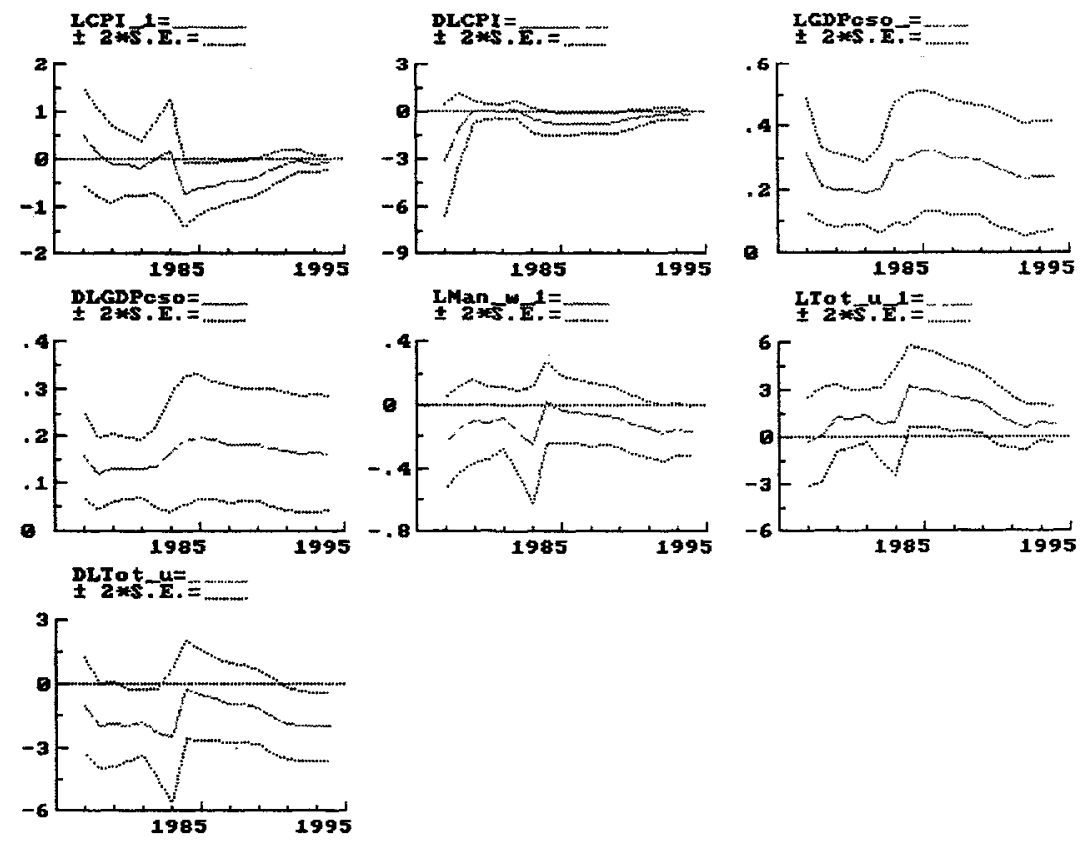

Nominal wages in the manufacturing sector seem unaffected in the long term by increased unemployment (see Table 6). This indicates that unemployment as a measure of the strength of demand in the labor market is not very important for manufacturing wages in the long run. Therefore, there exists no long-run trade-off between unemployment and wages. On the other hand, the short-term dynamics of the labor market affect wages through changes or growth in unemployment. The higher volatility or growth in the unemployment rate or informal sector activity the lower nominal wages, ceteris paribus.

We now consider the other demand pressure measure, namely GDP. The estimates reveal a positive effect on wages from increased demand. GDP affects wages both in the short and long term and an increase in economic activity impacts manufacturing sector wages positively.

Expectations and macro economic stability proxied by prices do only marginally affect wages in the long run and in the short run. Hence, nominal wages are not adjusted to price increases and, therefore, wages are eroded both in the short and long run. 
The estimated coefficient of nominal wages in levels is negative, less than one and is statistically significant and different from zero. The solved long-run equation with zero autonomous growth, $\left(\Delta \mathrm{w}=\Delta \mathrm{u}_{\mathrm{t}}=\Delta \mathrm{p}_{\mathrm{t}}=\Delta \mathrm{GDP}_{\mathrm{t}}=0\right)$, for manufacturing wages is:

$$
w=-4.1+4.5 u-0.6 p+1.4 \text { GDP }
$$

which describes a significant error-correction mechanism between wages, employment, GDP and prices. However, unemployment and prices seem to have no role to play in the error correction mechanism and, hence, on manufacturing wages in the longer term. The steady state solution of the model presented in Table 6 consistent with the growth of wages implied by the long-run equation (7) takes the form:

$$
\mathrm{w}_{\mathrm{t}}=-4.1+1.4 \mathrm{GDP}_{\mathrm{t}}-0.6 \mathrm{p}_{\mathrm{t}}+4.5 \mathrm{u}_{\mathrm{t}}-11.9 \Delta \mathrm{u}^{*}+0.98 \Delta \mathrm{GDP}^{*}-1.5 \Delta \mathrm{p}^{*}
$$

One implication for wages is that the equilibrium value of nominal wages is larger ceteris paribus the larger the steady state growth rate of GDP. Furthermore, the equilibrium value of nominal manufacturing wages is associated negatively with increases in the unemployment growth rate.

Different wage models are now considered, starting out analyzing whether manufacturing data fit a real wage specification. The results imply that real wages do respond to the strength of demand measured by GDP. Further, the real wage hypothesis seems to hold as the restrictions on the model, $w-p=0$, and the sum of the coefficients of $w, u, G D P$ and $p$ equal to zero cannot be rejected $(F(1,20)=0.65[0.43] ; F(1,20)=2.05[0.17]){ }^{11}$ The final model specification explains 72 percent of the variation in manufacturing wages.

\footnotetext{
${ }^{11}$ We reject the hypotheses that wages are determined by: (1) a first order error correction model with wages adjusting towards a static equilibrium that depends on prices; (2) a first order partial adjustment model with target value of wages depending on unemployment only.
} 


\subsection{Forecasting}

In addition to revealing marginal impacts of various variables on wages the forecasting performance of the models presented in Tables 3, 4 and 6 may also be of interest. Specifically, we are interested in whether our models are valid also after the implementation of ESAP in 1991.

Figure 13 shows forecasts and actual wages for the three models examined previously: (1) total wages with unemployment, CPI, productivity and policy variables; (2) total wages with GDP, CPI productivity and policy variables; and, (3) manufacturing wages. Additionally, 95 percent confidence bands are shown. From these plots, the level of wage growth seems to be captured well by our economic models, i.e., predicted wages fall within the confidence bands in 1992, 1993, and 1994.

\section{Figure 13}

Forecasting and actual values for the three wage models

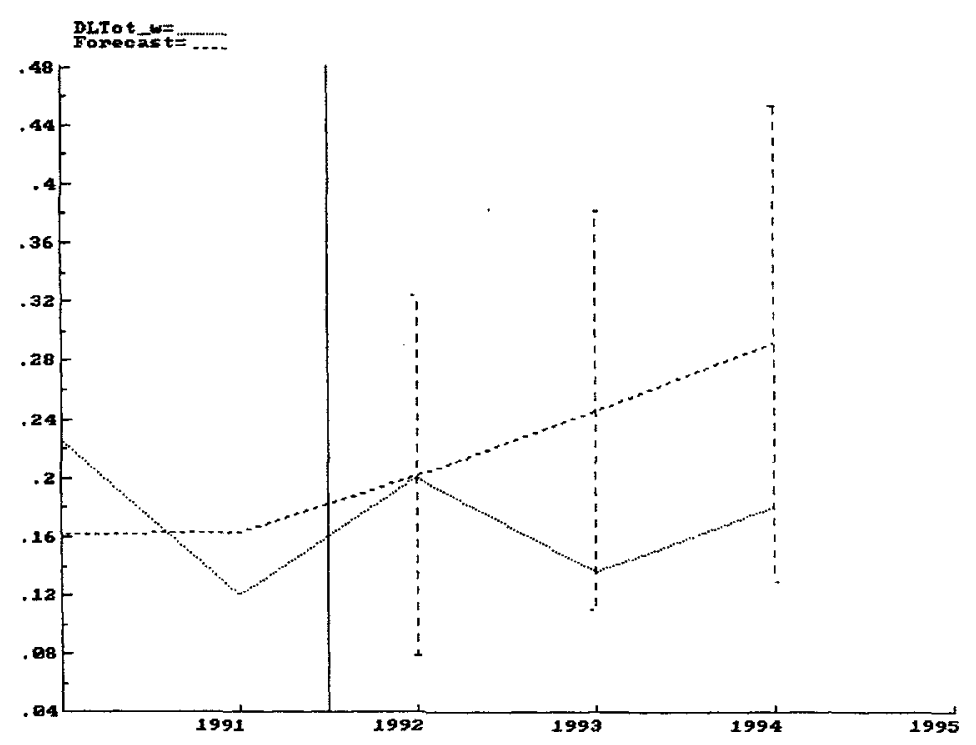



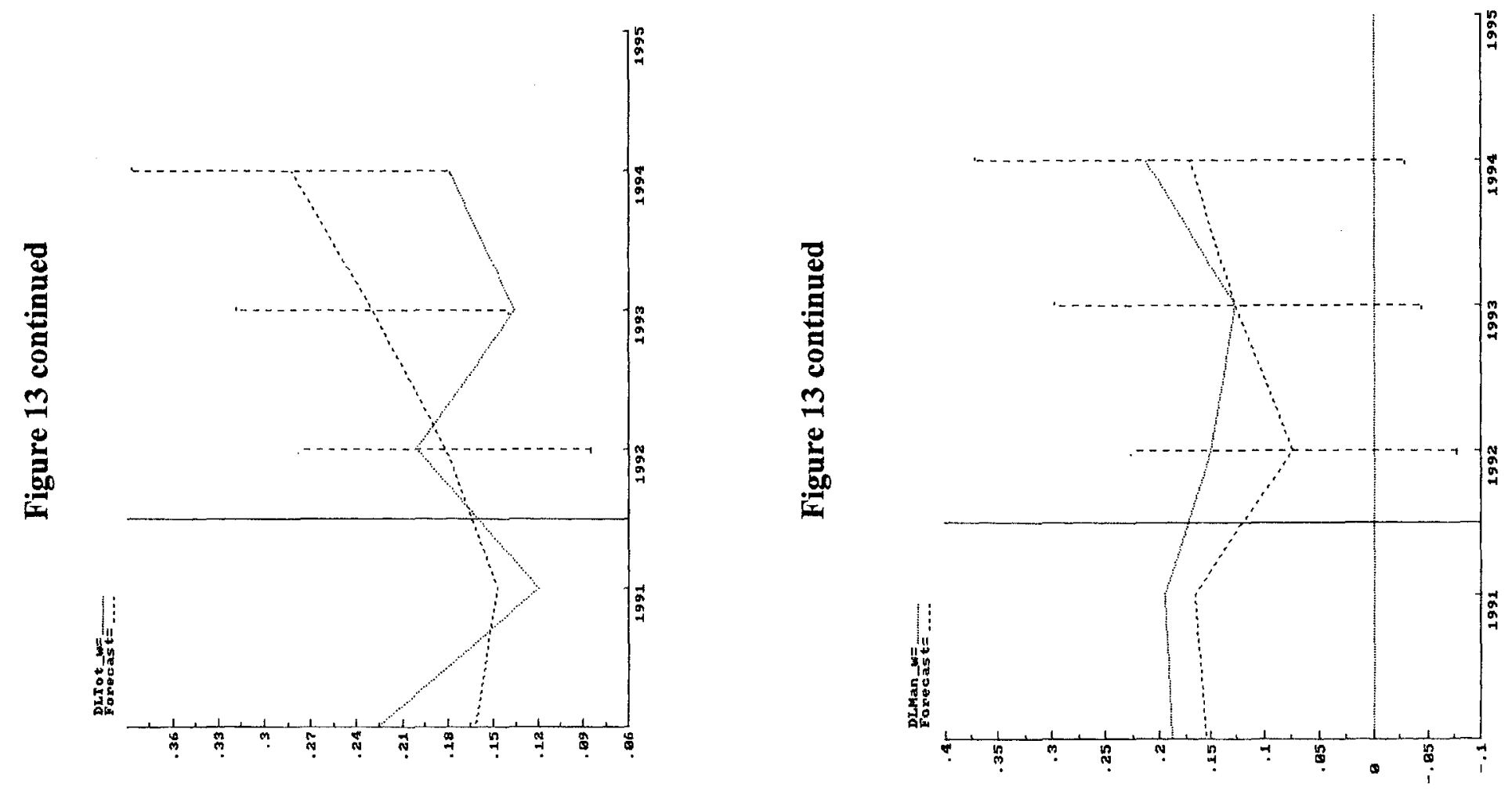


\section{Conclusion}

One of the main questions analyzed in this study is whether wages are flexible and we found that they are flexible both at the aggregate level and in the manufacturing sector. Additionally, a macro wage-curve is present in Zimbabwe explaining the relationship between nominal wage, productivity, economic activity, and prices. This is the case for both the entire economy and the manufacturing sector. Furthermore, no visual structural change has occurred in the labor markets after the ESAP was launched.

Inefficiencies due to loss in economic output are proxied by unemployment/informal sector activity or GDP. Both at the aggregate level and in the manufacturing sector, we find no significant negative effect on nominal wages from increased informal sector activity in the long term. This indicates that (institutional) rigidities are present in the labor market as there seems not to be any long-run trade-off between unemployment/informal sector activity and wages. One explanation may be that labor market institutions still play an important role in the Zimbabwean economy. Other explanations are that labor markets suffer from a so-called "insider-outsider" problem or firms pay efficiency wages. This is further analyzed in Verner (1998). However, in the short term wages are affected by changes in the unemployment rate. An increase affects nominal wages negatively, all else equal. The equilibrium value of nominal wages is smaller ceteris paribus the larger the steady state growth rate of the unemployment rate when it is positive. Hence, the equilibrium value of the nominal wage is associated negatively with increases in the unemployment growth rate or informal sector activity growth.

Expectations and macro economic stability, proxied by prices, affect nominal wages marginally in the long run but not in the short run. Wages do not instantaneously adjust to price increases and wages are eroded in the short run. In the longer term a price increase impact nominal wages positively. The same is true for productivity. The implication of the steady state equation is that the equilibrium value of nominal wages is larger ceteris paribus the larger is the steady state inflation rate when the latter is positive. 
Both in the short and long term wages are affected positively by increases in economic activity. The equilibrium value of nominal wages is larger the larger is the steady state growth rate of GDP. A one percentage point increase in GDP is associated with 0.3 percentage points increase in nominal wages, everything else equal. A ten-percentagepoints increase in prices or productivity impacts wages by 2.8 and 0.7 percentage points, respectively.

The forecasting performance indicates that the models are valid also after the implementation of ESAP in 1991. Therefore, the labor market in Zimbabwe is not very rigid and adjust to both positive and negative economic shocks. 


\section{References:}

Banerjee, A., Dolado, J., Galbraith, J.W. and Hendry, D.F (1993). Co-integration, Errorcorrection, and the Econometric Analysis of Non-stationary Data, Oxford University Press, Oxford.

Blanchflower, D. and Oswald, A. (1995). The Wage Curve, Cambridge: MIT Press.

Blunch, N.-H. and Verner, D. (1998), "Sectoral Economic Growth and the Dual Economy Model: Evidence from three Sub-Saharan Economies," Draft, World Bank, Washington, D.C.

Doornik, J. A. and Hendry, D. F (1995). PcGive 8.0 - An Interactive Econometric Modelling System, Chapman \& Hall.

Engle, R. F. and Granger, C. W. J. (1987). "Co-integration and Error Correction: Representation, Estimation and Testing," Econometrica, 55, 251-76.

Fallon, P. R. and R. E. Lucas (1991). "The Impact of Changes in Job Security in India and Zimbabwe," World Bank Economic Review, Vol. 5, No. 3, 395-413.

Fallon, P. R. and R. E. Lucas (1993). "Job Security Regulations and the Dynamic Demand for Industrial Labor in India and Zimbabwe," Journal of Development Economics, Vol 40, No. 2, 241-76.

Hendry, D. F. (1976). "The Structure of Simultaneous Equations Estimators," Journal of Econometrics, 4, 51-88.

Hendry, D. F. (1980). “Econometrics: Alchemy or Science?," Economica, 47, 387-406

Hoddinott, J. (1996). "Wages and Unemployment in an Urban African Labour Market," Economic Journal, 106, 1610-1626.

Knight, John (1996). "Labour Market Policies and Outcomes in Zimbabwe," Oxford: University of Oxford, Centre for the Study of African Economies, Processed: March.

Kremers, J.J.M., N.R. Ericsson, and J. Dolado, (1992). "The Power of Co-integration Tests," Oxford Bulletin of Economics and Statistics, 54, 325-48.

Phillips, A. W. (1958). "The Relation between Unemployment and the Rate of Change of Money Wages in the United Kingdom, 1861-1957," Economica, 25, 283-299.

Sargan, J. D. (1980). "Some Tests of Dynamic Specification for a Single Equation," Econometrica, 48, 879-97. 
Verner, D. (1998). "Are Wages and Productivity Affected by Human Capital Investment and International Trade? The case of Zimbabwe," Draft, World Bank, Washington, D.C. 


\section{Appendix A}

\section{Unit root tests}

\begin{tabular}{lccccc}
\hline \multicolumn{1}{c}{ Series } & t-adf & $\sigma$ & lag no & t-lag & t-prob \\
\hline LTot_w & -1.911 & 0.043 & 2 & -0.035 & 0.973 \\
LTot_w & -1.991 & 0.042 & 1 & 1.819 & 0.082 \\
LTot_w & -1.761 & 0.044 & 0 & & \\
LMan_w & -1.884 & 0.040 & 2 & -2.199 & 0.039 \\
LMan_w & -3.378 & 0.044 & 1 & 4.188 & 0.000 \\
LMan_w & -1.6531 & 0.057 & 0 & & \\
LGDPcso & -1.426 & 0.173 & 2 & -0.777 & 0.446 \\
LGDPcso & -2.283 & 0.172 & 1 & 1.425 & 0.168 \\
LGDPcso & -1.770 & 0.175 & 0 & & \\
LTot_u & -2.690 & 0.008 & 2 & -0.257 & 0.800 \\
LTot_u & -3.445 & 0.008 & 1 & 4.899 & 0.000 \\
LTot_u & -2.311 & 0.011 & 0 & & \\
LCPI & -0.397 & 0.053 & 2 & -0.045 & 0.965 \\
LCPI & -0.440 & 0.052 & 1 & 1.115 & 0.276 \\
LCPI & -0.103 & 0.052 & 0 & & \\
\hline
\end{tabular}

Notes: Critical values: $5 \%=-3.587,1 \%=-4.338$; constant and trend included. 


\section{Policy Research Working Paper Series}

\begin{tabular}{|c|c|c|c|c|}
\hline & Title & Author & Date & $\begin{array}{l}\text { Contact } \\
\text { for paper }\end{array}$ \\
\hline WPS2034 & $\begin{array}{l}\text { Information, Accounting, and the } \\
\text { Regulation of Concessioned } \\
\text { Infrastructure Monopolies }\end{array}$ & $\begin{array}{l}\text { Phil Burns } \\
\text { Antonio Estache }\end{array}$ & December 1998 & $\begin{array}{l}\text { G. Chenet-Smith } \\
36370\end{array}$ \\
\hline WPS2035 & $\begin{array}{l}\text { Macroeconomic Uncertainty and } \\
\text { Private Investrient in Developing } \\
\text { Countries: An Empirical Investigation }\end{array}$ & Luis Servén & December 1998 & $\begin{array}{l}\text { H. Vargas } \\
38546\end{array}$ \\
\hline WPS2036 & $\begin{array}{l}\text { Vehicles, Roads, and Road Use: } \\
\text { Alternative Empirical Specifications }\end{array}$ & $\begin{array}{l}\text { Gregory K. Ingram } \\
\text { Zhi Liu }\end{array}$ & December 1998 & $\begin{array}{l}\text { J. Ponchamni } \\
31022\end{array}$ \\
\hline WPS2037 & $\begin{array}{l}\text { Financial Regulation and } \\
\text { Performance: Cross-Country } \\
\text { Evidence }\end{array}$ & $\begin{array}{l}\text { James R. Barth } \\
\text { Gerard Caprio, Jr. } \\
\text { Ross Levine }\end{array}$ & January 1999 & $\begin{array}{l}\text { A. Yaptenco } \\
38526\end{array}$ \\
\hline WP\$2038 & $\begin{array}{l}\text { Good Governance and Trade Policy: } \\
\text { Are They the Keys to Africa's Global } \\
\text { Integration and Growth? }\end{array}$ & $\begin{array}{l}\text { Francis } \mathrm{Ng} \\
\text { Alexander Yeats }\end{array}$ & January 1999 & $\begin{array}{l}\text { L. Tabada } \\
36896\end{array}$ \\
\hline WPS2039 & $\begin{array}{l}\text { Reforming Institutions for Service } \\
\text { Delivery: A Framework for Developme } \\
\text { Assistance with an Application to the } \\
\text { health, Nutrition, and Population } \\
\text { Portfolio }\end{array}$ & $\begin{array}{l}\text { Navin Girishankar } \\
\text { ent }\end{array}$ & January 1999 & $\begin{array}{l}\text { B. Casely-Hayford } \\
34672\end{array}$ \\
\hline WPS2040 & $\begin{array}{l}\text { Making Negotiated Land Reform } \\
\text { Work: Initial Experience from } \\
\text { Brazil, Colombia, and South Arrica }\end{array}$ & Klaus Deininger & January 1999 & $\begin{array}{l}\text { M. Fernandez } \\
33766\end{array}$ \\
\hline WPS2041 & Aid Allocation and Poverty Reduction & $\begin{array}{l}\text { Paul Collier } \\
\text { David Dollar }\end{array}$ & January 1999 & $\begin{array}{l}\text { E. Khine } \\
37471\end{array}$ \\
\hline WPS2042 & $\begin{array}{l}\text { Determinants of Motorization and } \\
\text { Road Provision }\end{array}$ & $\begin{array}{l}\text { Gregory K. Ingram } \\
\text { Zhi Liu }\end{array}$ & January 1999 & $\begin{array}{l}\text { J. Ponchamni } \\
31022\end{array}$ \\
\hline PWS2043 & Demand for Public Safety & $\begin{array}{l}\text { Menno Pradhan } \\
\text { Martin Ravallion }\end{array}$ & January 1999 & $\begin{array}{l}\text { P. Sader } \\
33902\end{array}$ \\
\hline WPS2044 & $\begin{array}{l}\text { Trade, Migration, and Welfare: } \\
\text { The Impact of Social Capital }\end{array}$ & Maurice Schiff & January 1999 & $\begin{array}{l}\text { L. Tabada } \\
36896\end{array}$ \\
\hline WPS2045 & $\begin{array}{l}\text { Water Challenge and institutiona! } \\
\text { Response (A Cross-Country } \\
\text { Perspective) }\end{array}$ & $\begin{array}{l}\text { R. Maria Saleth } \\
\text { Ariel Dinar }\end{array}$ & January 1999 & $\begin{array}{l}\text { F. Toppin } \\
30450\end{array}$ \\
\hline WPS2046 & $\begin{array}{l}\text { Restructuring of insider-Dominated } \\
\text { Firms }\end{array}$ & Simeon Djankov & January 1999 & $\begin{array}{l}\text { R. Vo } \\
33722\end{array}$ \\
\hline WPS2047 & $\begin{array}{l}\text { Ownership Structure and Enterprise } \\
\text { Restructuring in Six Newly } \\
\text { Independent States }\end{array}$ & Simeon Djankov & February 1999 & $\begin{array}{l}\text { R. Vo } \\
33722\end{array}$ \\
\hline
\end{tabular}


Policy Research Working Paper Series

\begin{tabular}{|c|c|c|c|c|}
\hline & Title & Author & Date & $\begin{array}{l}\text { Contact } \\
\text { for paper }\end{array}$ \\
\hline WPS2048 & $\begin{array}{l}\text { Corruption in Economic } \\
\text { Development: Beneficial Grease, } \\
\text { Minor Annoyance, or Major Obstacle? }\end{array}$ & Shang-Jin Wei & February 1999 & $\begin{array}{l}\text { C. Bernardo } \\
31148\end{array}$ \\
\hline WPS2048 & $\begin{array}{l}\text { Household Labor Supply, } \\
\text { Unemployment, and Minimum Wage } \\
\text { Legislation }\end{array}$ & $\begin{array}{l}\text { Kaushik Basu } \\
\text { Garance Genicot } \\
\text { Joseph E. Stiglitz }\end{array}$ & February 1999 & $\begin{array}{l}\text { M. Mason } \\
30809\end{array}$ \\
\hline NPS2050 & $\begin{array}{l}\text { Measuring Aid Flows: A Now } \\
\text { Approach }\end{array}$ & $\begin{array}{l}\text { Charles C. Chang } \\
\text { Eduardo Fernández-Arias } \\
\text { Luis Servén }\end{array}$ & February 1999 & $\begin{array}{l}\text { E. Khine } \\
37471\end{array}$ \\
\hline WPS2051 & $\begin{array}{l}\text { How Stronger Protection of } \\
\text { Intellectual Property Rights Affects } \\
\text { International Trade Flows }\end{array}$ & $\begin{array}{l}\text { Carsten Fink } \\
\text { Carlos A. Primo Braga }\end{array}$ & Fabruary 1999 & $\begin{array}{l}\text { L. Willens } \\
85153\end{array}$ \\
\hline
\end{tabular}

